\title{
UTICAJ NEKIH DETERMINANTI NA RAZVOJ KARIJERE OFICIRA VOJSKE SRBIJE
}

\author{
Jan Marček* \\ Vladimir Ristić, Dragan Bojanić \\ Univerzitet odbrane u Beogradu
}

Qazvoj karijere oficira je veoma složen proces i determinisan je brojnim činiocima. Osnovni problem ovog istraživanja je bio kakav uticaj imaju pojedine determinante na proces razvoja karijere oficira, kao što su: normativno-pravne pretpostavke; različiti subjekti upravljanja ljudskim resursima i planiranje, selekcija, školovanje, usavršavanje i raspoređivanje oficira. Takođe je istraženo kakvi su efekti pravilnog razvoja karijere oficira i da li postoje razlike u proceni uticaja pojedinih determinanti na razvoj karijere oficira. Shodno tome, osnovni cilj ovog istraživanja je bio da se ispita kakav uticaj ostvaruju neke determinante na razvoj karijere oficira, kakvi su efekti pravilnog razvoja karijere oficira i da li postoje razlike u proceni uticaja pojedinih determinanti na razvoj karijere oficira.

Osim opšteg cilja, za ovo istraživanje definisano je pet zadatka istraživanja, i to: 1) Utvrditi da li normativno-pravne pretpostavke u značajnoj meri obezbeđuju uspešan razvoj karijere oficira; 2) Utvrditi kakav je uticaj različitih subjekata upravljanja ljudskim resursima na razvoj karijere oficira; 3) Utvrditi kakav je uticaj planiranja, selekcije, školovanja, usavršavanja i raspoređivanja oficira na razvoj njihove karijere; 4) Utvrditi kakvi su efekti pravilnog razvoja karijere oficira i 5) Utvrditi da li postoje razlike između pojedinih kategorija oficirskog kadra po pitanju procene pojedinih činilaca na uspešnost razvoja karijere oficira uzimajući u obzir njihova personalna, statusna i andragoška obeležja.

Rezultati istraživanja su pokazali da ispitivane determinante, osim prve, ostvaruju značajan uticaj na razvoj karijere oficira i da pravilan razvoj karijere oficira u značajnoj meri utiče na optimalno korišćenje ljudskih resursa, motivisanost starešinskog kadra za postizanje odličnih rezultata i napredovanje u struci, kao i na izgrađivanje operativnih sposobnosti Vojske. Takođe, utvrđene su značajne razlike između pojedinih kategorija oficirskog kadra po pitanju procene pojedinih činilaca na uspešnost razvoja karijere oficira, uzimajući u obzir njihova personalna, statusna i andragoška obeležja.

Ključne reči: razvoj karijere oficira, Vojska Srbije, upravljanje ljudskim resursima, operativne sposobnosti jedinica Vojske Srbije

* Prof. dr Jan Marček je pukovnik u penziji. 


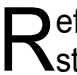
eforma sistema odbrane je neprekidan proces. Dinamični bezbednosni procesi stalno uslovljavaju nova prilagođavanja. Osnovni element u tom procesu, svakako, čine ljudski resursi, pa se njihovom izboru i vođenju mora posvetiti posebna pažnja. U vojnoj organizaciji se neprekidno traga za mehanizmima koji će najsposobnijima i najkompetentnijima dati priliku da komanduju i rukovode, koji će svakog čoveka postaviti na mesto sa kojeg će sistemu najviše koristiti, uvažavajući istovremeno lične potrebe, ambicije i potrebe sistema. Danas, kada je sistem odbrane suptilni spoljnopolitički instrument, garant bezbednosti i nadasve zalog države u njenom nesmetanom ekonomskom razvoju, pažnja koja se posvećuje izboru i vođenju kadra srazmerno je veća.

U osnovi pravilnog izbora kandidata za odgovarajuće dužnosti treba da budu merljivi kriterijumi preko kojih se može celovito vrednovati njihov potencijal. Rangiranjem kandidata na osnovu objektivno merljivih kriterijuma, uz ispunjenje uslova za fizičku i zdravstvenu sposobnost, kao i zadovoljenjem kriterijuma za obavljanje određene dužnosti, ovi kriterijumi mogu pomoći da se izbegne negativna selekcija i da do najviših dužnosti u organizaciji dolaze najbolji, najpouzdaniji i najsposobniji kandidati. Na taj način će moći da se zadovolji princip da najsposobniji kandidati budu na pravom mestu.

Vojna profesija je svuda u svetu po mnogo čemu specifična. Posebna specifičnost jesu znanja koja se stiču u vojnim školama i mogu se koristiti samo u vojnoj organizaciji, dok su u drugim državnim, društvenim i privrednim sistemima veoma malo primenljiva. Stoga bi mladom čoveku, koji se opredelio za ovo izuzetno teško i časno zanimanje, trebalo omogućiti da planira svoj karijerni put. Upravo zbog ovoga, tok u službi treba da bude predvidiv, sa jasnim i dugoročno opredeljenim kriterijumima u smislu usavršavanja, unapređivanja i postavljenja na formacijska mesta (dužnosti).

Unutar postojećeg sistema odbrane značajan segment reformskog procesa predstavlja uspostavljanje kriterijuma za razvoj karijere profesionalnih pripadnika u Ministarstvu odbrane i Vojsci Srbije. ${ }^{1} \mathrm{Na}$ osnovu dosadašnje analize postojećeg sistema upravljanja ljudskim resursima, kao i pojedinih stranih iskustava, došlo se do modela koji će, pre svega, oficirima, a potom i ostalim kategorijama kadra, omogućiti profesionalni razvoj, kod kojeg će svaki pripadnik znati svoje mesto unutar roda ili službe, odnosno kakav tip karijere i napredovanja mu predstoji.

Aktivnosti koje sprovode organizacione celine za upravljanje ljudskim resursima profesionalnom pripadniku Vojske pružaju informacije o sopstvenoj vojnoj karijeri i čine je predvidivom, na osnovu čega može znati svoje trenutno mesto u sistemu, šta mu se nudi u vojnoj karijeri, pod kojim uslovima i na koji način. Komandovanje i organizacione celine za upravljanje ljudskim resursima prate, organizuju, usmeravaju i ocenjuju profesionalne pripadnike, obezbeđuju njihov sopstveni razvoj i razvoj Vojske, pružajući podršku, koja se ogleda u: postavljanju ciljeva karijere (davanje stručne, realne i jasne perspektive koju mogu da ostvare u jedinici i nudeći veći broj mogućnosti za ostvarivanje tih ciljeva); razmatranju karijere (pružanje pomoći u preispitivanju ciljeva i rezultata dotadašnje karijere);

\footnotetext{
${ }^{1} \mathrm{U}$ Vojsci Srbije, karijera se posmatra kao vertikalno i horizontalno pomeranje formacijskih pozicija profesionalnih pripadnika i predstavlja šire shvatanje svih promena vezanih za profesionalne pripadnike unutar Vojske (Doktrina upravljanja ljudskim resursima Vojske Srbije, Nacrt, 2010, str. 15).
} 
izradi plana razvoja karijere (davanje informacija potrebnih za realizaciju ciljeva); pružanju povratnih informacija u vezi s karijerom (realno procenjivanje aktuelnih rezultata rada i potencijala koji su u vezi sa karijerom).

Profesionalnim razvojem karijere oficira obezbeđuje se odgovarajući kadar za popunu najodgovornijih dužnosti u sistemu odbrane. Radi planiranja napredovanja sastavljaju se jedinstvene rang liste oficira po rodovima - službama, odnosno, po tipovima karijere. Vođenje oficira u službi u okviru roda-službe kojoj oficir pripada, načelno se obavlja zaključno sa činom kapetana. Vođenje usmeravanjem na dužnosti, načelno se obavlja od čina majora, u jednom od sledećih tipova karijere: komandno-operativna; štabno-funkcionalna; karijera u planiranju odbrane; karijera ljudskih resursa; logistička; obaveštajnobezbednosna i nastavno-naučna karijera.

Komandno-operativna karijera načelno obuhvata: komandne i rukovodeće dužnosti; operativne dužnosti (funkcije planiranja, organizovanja, upravljanja i kontrole); dužnosti u organima za obuku i dužnosti u Inspektoratu odbrane. Štabno-funkcionalna karijera obuhvata: referentske i izvršne (štabne) dužnosti u organima komandi i ustanova; dužnosti u organima veze i informatike; dužnosti u organima za odnose sa javnošću i civilno-vojnu saradnju; dužnosti u organima finansijske službe i dužnosti u organima pravne službe. Karijera u planiranju odbrane obuhvata: dužnosti u organima za strategijsko planiranje; dužnosti u organima za programiranje i budžetiranje; dužnosti u organima za organizacijsko-mobilizacijske poslove i dužnosti u organima za međunarodnu saradnju. Karijera ljudskih resursa obuhvata: dužnosti u organima za personalne poslove; dužnosti u organima za sistemska i statusna pitanja; dužnosti u organima za školovanje i usavršavanje; dužnosti u organima za moral i psihološki rad i dužnosti u organima za obaveze odbrane. Logistička karijera obuhvata: dužnosti u organima opšte logistike; dužnosti u organima za snabdevanje; dužnosti u organima za održavanje; dužnosti u organima za zdravstveno obezbeđenje; dužnosti u organima za infrastrukturu i dužnosti u organima za transport. Obaveštajno-bezbednosna karijera obuhvata: dužnosti u organima za obaveštajne poslove; dužnosti u organima bezbednosti i dužnosti u organima za vojnopolicijske poslove. Nastavno-naučna karijera obuhvata: nastavne dužnosti u vojnoškolskim ustanovama i dužnosti u organima za naučnoistraživački rad.

Za praćenje i modelovanje razvoja karijere oficira neophodno je obezbediti odgovarajući skup pokazatelja koji određuju moguće tokove razvoja karijere.

\section{Problem}

Razvoj karijere oficira je veoma složen proces i determinisan je brojnim činiocima. Osnovni problem ovog istraživanja je bio kakav uticaj imaju pojedine determinante na proces razvoja karijere oficira, kao što su: normativno-pravne pretpostavke; različiti subjekti upravljanja ljudskim resursima i planiranje, selekcija, školovanje, usavršavanje i raspoređivanje oficira. Takođe se postavlja pitanje kakvi su efekti pravilnog razvoja karijere oficira na optimalno iskorišćenje ljudskih i materijalnih resursa, da u jedinicama/ustanovama Vojske Srbije komanduju/rukovode najsposobniji i najkompetentniji oficiri, na motivisanost starešinskog kadra za postizanje odličnih rezultata na formacij- 
skoj dužnosti, na motivisanost starešinskog kadra za profesionalnim razvojem u struci i na izgrađivanje operativnih sposobnosti jedinica Vojske Srbije. I na kraju, postavlja se pitanje da li postoje razlike među ispitanicima u proceni uticaja pojedinih determinanti na razvoj karijere oficira uzimajući u obzir njihova personalna, statusna i andragoška obeležja. Shodno tome, osnovni cilj ovog istraživanja je bio da se ispita kakav uticaj ostvaruju neke determinante na razvoj karijere oficira, kakvi su efekti pravilnog razvoja karijere oficira i da li postoje razlike u proceni uticaja pojedinih determinanti na razvoj karijere oficira.

Osim opšteg cilja, za ovo istraživanje je definisano pet zadatka istraživanja, i to: 1) Utvrditi da li normativno-pravne pretpostavke u značajnoj meri obezbeđuju uspešan razvoj karijere oficira; 2) Utvrditi kakav je uticaj različitih subjekata upravljanja ljudskim resursima na razvoj karijere oficira; 3) Utvrditi kakav je uticaj planiranja, selekcije, školovanja, usavršavanja i raspoređivanja oficira na razvoj njihove karijere; 4)Utvrditi kakvi su efekti pravilnog razvoja karijere oficira i 5) Utvrditi da li postoje razlike između pojedinih kategorija oficirskog kadra (prema njihovim personalnim, statusnim i andragoškim obeležjima), po pitanju procene pojedinih činilaca na uspešnost razvoja karijere oficira.

Nezavisne varijable u ovom istraživanju su činile osnovne determinante razvoja karijere oficira (normativno-pravne pretpostavke; uticaj različitih subjekata upravljanja ljudskim resursima na razvoj karijere oficira; uspešnost procesa razvoja karijere oficira i personalna, statusna i andragoška obeležja oficira).

\section{Normativno-pravne pretpostavke obezbeđuju uspešan razvoj karijere oficira}

Indikatori: 1) Uredba o stanjima u službi i unapređivanju oficira, podoficira i profesionalnih vojnika u potpunosti omogućava uslove za adekvatan razvoj karijere oficira; 2) Ponovno uvođenje polaganja ispita za čin majora bi unapredilo proces razvoja karijere oficira; 3) Normativno-pravne pretpostavke čine proces razvoja oficira u dovoljnoj meri predvidivim; 4) Odredbe Zakona o Vojsci Srbije omogućavaju pravilan i ravnomeran razvoj karijere oficira i 5) Godišnji plan školovanja i obuke u Ministarstvu odbrane predstavlja najvažniji dokument u sklopu individualnog planiranja razvoja karijere oficira.

\section{Uticaj različitih subjekata upravljanja ljudskim resursima na razvoj karijere oficira}

Indikatori: 1) Na razvoj karijere oficira utiču različiti subjekti; 2) Pripadnost određenom rodu-službi može u značajnoj meri uticati na razvoj karijere oficira; 3) Raspoređivanje oficira po završetku školovanja/usavršavanja u značajnoj meri utiče na dalji razvoj njegove karijere; 4) Na raspoređivanje oficira nakon završetka školovanja/usavršavanja u najvećoj meri utiču različiti faktori; 5) Socijalna mreža (grupisanje) u smislu geografskog porekla, rođačkih linija i slično ima uticaj na razvoj karijere oficira i 6) Uprava za kadrove Sektora za ljudske resurse (SLjR) Ministarstvu odbrane u dovoljnoj meri obezbeđuje potrebne informacije o mogućnostima za razvoj karijere oficira. 


\section{Kvalitetno planiranje, selekcija, raspoređivanje na dužnost, horizontalno i vertikalno pomeranje na dužnostima i obavljanje dužnosti nastavnika ima uticaja na razvoj karijere oficira}

Indikatori: 1) Kvalitetno planiranje razvoja starešinskog kadra umnogome utiče na uspešnost razvoja karijere oficira; 2) Pravilna selekcija oficira za upućivanje na školovanja/usavršavanja predstavlja osnovni preduslov za uspešnost u razvoju njihove karijere; 3) Raspoređivanje oficira na dužnost nakon završetka školovanja/usavršavanja trebalo bi da se prvenstveno obavlja na osnovu postignutog uspeha tokom školovanja/usavršavanja; 4) Pravilan razvoj karijere podrazumeva ne samo pomeranje oficira (u hijerarhiji VS/MO) po vertikali, već i po horizontali, čime se stiču dodatne stručne kompetencije; 5) U cilju pravilnog razvoja karijere, oficir bi trebao tokom radnog veka da se najmanje jednom (a poželjno i više puta) premešta iz Vojske Srbije u Ministarstvo odbrane, i obrnuto i 6) U toku profesionalne karijere, oficiri na najvišim dužnostima u Vojsci Srbije trebalo bi da provedu izvesno vreme na odgovarajućim nivoima visokoškolskog vojnog obrazovanja u ulozi nastavnika;

\section{Uticaj efekata pravilnog razvoja karijere oficira na izgrađivanje Vojske}

Indikatori: 1) Efekti pravilnog razvoja karijere oficira značajno doprinose optimalnoj iskorišćenosti ljudskih i materijalnih resursa njihovih jedinica; 2) Pravilnim razvojem karijere oficira obezbeđuje se da u jedinicama/ustanovama Vojske Srbije komanduju/rukovode najsposobniji i najkompetentniji oficiri; 3) Efekti pravilnog razvoja karijere oficira neposredno utiču na motivisanost starešinskog kadra za postizanje odličnih rezultata na formacijskoj dužnosti; 4) Pravilan razvoj karijere oficira umnogome utiče na motivisanost starešinskog kadra za profesionalnim razvojem u struci (obrazovanje tokom života) i 5) Efekti pravilnog razvoja karijere oficira neposredno utiču na razvoj i održavanje operativnih sposobnosti njihovih jedinica, kao i Vojske Srbije u celini.

Osim toga, nezavisne varijable činila su sledeća personalna, statusna i andragoška obeležja ispitanika: starost; penzijski staž; poreklo; dužnost; čin; pripadnost određenom rodu-službi; stepen obrazovanja; najviše vojno obrazovanje; najviše vojno usavršavanje; ocena sa školovanja; poznavanje vrste stranog jezika; stepen poznavanja stranog jezika i vrste završenih kurseva.

Zavisnu varijablu u ovom istraživanju je činila procena uticaja pojedinih determinanti na uspešnost razvoja karijere oficira, kao i procena efekata pravilnog razvoja karijere oficira na izgradnju Vojske Srbije.

\section{Metode istraživanja}

U istraživanju je korišćena deskriptivna metoda, a prikupljanje podataka je obavljeno pomoću anketiranja kao istraživačke tehnike (postupka). Anketiranje je obavljeno pomoću upitnika. Prvi deo upitnika činili su podaci o uzorku ispitanika, a drugi deo upitnika modaliteti četiri uticajna činioca na razvoj karijere oficira, a kao peti element - efekti pravilnog razvoja karijere oficira. Uticaj pojedinih determinanti na razvoj karijere oficira procenjivan je na osnovu petostepene skale Likertovog tipa. 
Uzorak istraživanja je činilo 219 ispitanika - oficira različitih personalnih, statusnih i andragoških obeležja: starost (1/do 35 godina; 2/35-40 godina; 3/40-45 godina; 4/preko 45 godina); penzijski staž (1/do 10 godina; 2/11-20 godina; 3/21-30 godina; 4/preko 30 godina); poreklo (1/radničko; 2/zemljoradničko; 3/službeničko i 4/ostalo); dužnost (1/komandna; 2/rukovodeća; 3/ostale), čin (1/poručnik; 2/kapetan; 3/major; 4/potpukovnik; 5/pukovnik); pripadnost rodu-službi (1/pešadija; 2/artiljerija; 3/OMJ; 4/inžinjerija; 5/rečne jedinice; 6/ARJ PVD; 7NOJ; 8/tehnička služba; 9/saobraćajna služba; 10/intendantska služba; 11) služba telekomunikacija; 12/ služba informatike; 13/El i PED; 14/avijacija; 15/finansijska služba; 16/personalna služba; 17/vojna policija; 18/sanitetska služba; 19/služba bezbednosti); stepen obrazovanja (1/visoko; 2/master; 3/specijalizacija; 4/magistar; 5/doktor nauka); najviše vojno obrazovanje (1/vojna gimnazija ili srednja vojna škola; 2/vojna akademija; 3/specijalizacija; 4/magisterijum; 5/doktorat); najviše vojno usavršavanje (1/komandno-štabno usavršavanje; 2/generalštabno usavršavanje; 3)osnovni komandno-štabni kurs i 4/ostalo), ocena sa školovanja $(1 / 6,00-7,00 ; 2) 7,01-8,00 ; 3) 8,01-9,00,4 / 9,01-10,00)$, poslednja službena ocena $(1 / 2,50-3,00 ; 2 / 3,01-3,50 ; 3 / 3,51-4,00 ; 4 / 4,01-4,50 ; 5 / 4,51-5,00)$, poznavanje vrste stranog jezika (1/engleski; 2/ruski, 3/nemački; 4/ostali jezici), stepen poznavanja stranog jezika (1/prvi stepen; 2/drugi stepen-kategorija Vojne akademije; 3/STANAG 1 i 4/STANAG 2 i vrste završenih kurseva (1/stručni; 2/obaveštajni; 3)bezbednosni i 4)ostali).

Prema kriterijumu personalnog obeležja "starost", najveći procenat ispitanika pripada grupi od 35 do 40 godina (46,6\%), a najmanji procenat ispitanika - grupi starosti preko 45 godina $(8,7 \%)$. Kada je reč o obeležju „penzijski staž“, najveći procenat ispitanika pripada grupi sa 11 do 20 godina penzijskog staža (65,3\%), a najmanji procenat ispitanika grupi sa stažom preko 30 godina $(4,1 \%)$. Prilikom razmatranja "porekla" ispitanika, utvrđeno je da najveći procenat ispitanika potiče iz radničkih porodica $(70,3 \%)$, a najmanji iz zemljoradničkih $(7,5 \%)$. U odnosu na statusno obeležje "dužnost" ispitanici su svrstani u tri grupe (komandna, rukovodeća i ostale). U strukturi uzorka sve tri grupe ispitanika imaju podjednaku zastupljenost - približno oko jedne trećine $(33,8 ; 32 \%$ i $34,2 \%)$. Struktura uzorka prema statusnom obeležju "čina", pokazuje da najveći procenat ispitanika pripada grupi sa činom kapetana $(49,3 \%)$, a najmanje grupi poručnika $(0,5 \%)$ i pukovnika $(0,9 \%)$. Među statusna obeležja ispitanika svrstana je i "pripadnost određenom rodu-službi". U odnosu na ovo obeležje, najveći procenat ispitanika pripada grupi pešadija (16,9\%), zatim artiljerija $(13,7 \%)$, služba telekomunikacije $(11 \%)$ i tehnička služba $(10 \%)$. Kada je reč o "stepenu obrazovanja", najveći procenat ispitanika pripada grupi sa visokim vojnim obrazovanjem $(83,1 \%)$. Dobijeni rezultati pokazuju da najveći procenat ispitanika pripada grupi sa završenom Vojnom akademijom (79,9\%). U odnosu na obeležje "najviše vojno usavršavanje", rezultati ispitivanja pokazuju da najveći procenat ispitanika pripada grupi koja je završila osnovni komandno-štabni kurs $(56,6 \%)$, zatim komandno-štabno usavršavanje $(14,2 \%)$ i generalštabno usavršavanje $(12,3 \%)$. Najveći procenat ispitanika poznaje engleski jezik $(77,2 \%)$, a mnogo manje njih poznaje ruski jezik $(14,2 \%)$, kao i ostale strane jezike. Rezultati ispitivanja pokazuju da najveći broj ispitanika poznaje prvi stepen engleskog jezika (32,9\%), zatim drugi stepen-kategorija Vojne akademije $(28,3 \%)$, STANAG $2(22,8 \%)$ i STANAG $1(13,2 \%)$.

Statistička obrada podataka je obuhvatala određivanje osnovnih statističkih parametara (frekvencija i procenat) i utvrđivanje statističke značajnosti razlika između pojedinih kategorija oficira po pitanju procene uticaja pojedinih činilaca na uspešnost razvoja karijere oficira pomoću analize varijanse. 


\section{Rezultati istraživanja}

U sklopu interpretacije rezultata istraživanja najpre su prikazani statistički podaci koji se odnose na uticaj pojedinih činilaca na razvoj karijere oficira, uz korišćenje određenog broja indikatora. Za to su korišćeni rezultati deskriptivne statistike (frekvencija i procenti). Nakon toga je obavljena analiza razlika u proceni uticaja pojedinih činilaca u odnosu na pojedina personalna, statusna i andragoška obeležja ispitanika, uz korišćenje analize varijanse.

\section{Uticaj normativno-pravnih pretpostavki na razvoj karijere oficira}

Uticaj normativno-pravnih pretpostavki na uspešan razvoj karijere oficira razmatran je pomoću sledećih indikatora: 1) Uredba o stanjima u službi i unapređivanju oficira, podoficira i profesionalnih vojnika u potpunosti omogućava uslove za adekvatan razvoj karijere oficira; 2) Ponovno uvođenje polaganja ispita za čin majora bi unapredilo proces razvoja karijere oficira; 3) Normativno-pravne pretpostavke čine proces razvoja karijere oficira predvidivim u dovoljnoj meri; 4) Odredbe Zakona o Vojsci Srbije omogućavaju pravilan i ravnomeran razvoj karijere oficira i 5) Godišnji plan školovanja i obuke u Ministarstvu odbrane predstavlja najvažniji dokument u sklopu individualnog planiranja razvoja karijere oficira.

Rezultati procene ispitanika po pitanju uticaja pojedinih indikatora normativno-pravnih pretpostavki prikazani su u tabeli 1. Kada je reč o "Uredbi o stanjima u službi i o unapređivanju oficira, podoficira i profesionalnih vojnika i njenom uticaju na razvoj karijere oficira", svega 22 odsto ispitanika se izjašnjava u prilog ovoj tvrdnji, a više od jedne trećine ispitanika $(39,3 \%)$ smatra da pomenuta uredba ne doprinosi uspešnom razvoju karijere oficira. Za ovakav rezultat se pretpostavlja da ispitanici u nedovoljnoj meri poznaju sadržaj uredbe, pa samim tim ne mogu adekvatno da procene uticaj ovog dokumenta na razvoj karijere oficira.

Nešto bolji rezultati su postignuti u oceni doprinosa „Ponovnog uvođenja ispita za čin majora u model profesionalnog usavršavanja oficira na razvoj karijere oficira" $(38,4 \%)$. Međutim, skoro jedna trećina ispitanika smatra da ovaj postupak ne bi doprineo uspešnom razvoju karijere oficira. Ako se tome doda činjenica da je čak jedna trećina ispitanika neodlučna po ovom pitanju, može se zaključiti da skoro dve trećine ispitanika nema pozitivan stav prema uvođenju ovog modela usavršavanja $(61,7 \%)$. Verovatno je na ovakav rezultat uticalo „duže odsustvo" ovog modela profesionalnog usavršavanja oficira u sistemu vojnog školstva.

Tabela 1 - Normativno-pravne pretpostavke obezbeđuju uspešan razvoj karijere oficira

\begin{tabular}{|c|c|c|c|c|c|c|c|c|c|}
\hline & \multirow{4}{*}{ Normativno-pravne pretpostavke } & \multicolumn{8}{|c|}{ Uticaj na razvoj karijere oficira } \\
\hline & & \multicolumn{8}{|c|}{ Odgovori ispitanika } \\
\hline & & \multicolumn{2}{|c|}{$\mathrm{Da}$} & \multicolumn{2}{|c|}{$\mathrm{Ne}$} & \multicolumn{2}{|c|}{ Ne znam } & \multicolumn{2}{|c|}{ Ukupno } \\
\hline & & $\mathrm{F}$ & $\%$ & $\mathrm{~F}$ & $\%$ & $\mathrm{~F}$ & $\%$ & $\mathrm{~F}$ & $\%$ \\
\hline 1. & $\begin{array}{l}\text { Uredba o stanjima u službi i } \\
\text { unapređivanju oficira, podoficira i } \\
\text { profesionalnih vojnika u potpunosti } \\
\text { omogućava uslove za adekvatan razvoj } \\
\text { karijere oficira }\end{array}$ & 48 & 21.9 & 86 & 39.3 & 85 & 38.8 & 219 & 100 \\
\hline 2. & $\begin{array}{l}\text { Ponovno uvođenje polaganja ispita za } \\
\text { čin majora bi unapredilo proces razvoja } \\
\text { karijere oficira }\end{array}$ & 84 & 38.4 & 65 & 29.7 & 70 & 32.0 & 219 & 100 \\
\hline
\end{tabular}




\begin{tabular}{|c|l|c|c|c|c|c|c|c|c|}
\hline 3. & $\begin{array}{l}\text { Normativno-pravne pretpostavke čine } \\
\text { proces razvoja oficira u dovoljnoj meri } \\
\text { predvidivim }\end{array}$ & 68 & 31.1 & 45 & 20.5 & 106 & 48.4 & 219 & 100 \\
\hline 4. & $\begin{array}{l}\text { Odredbe Zakona o Vojsci Srbije } \\
\text { omogućavaju pravilan i ravnomeran } \\
\text { razvoj karijere oficira }\end{array}$ & 85 & 38.8 & 39 & 17.8 & 95 & 43.4 & 219 & 100 \\
\hline 5. & $\begin{array}{l}\text { Godišnji plan školovanja i obuke u } \\
\text { Ministarstvu odbrane predstavlja } \\
\text { najvažniji dokument u sklopu } \\
\text { individualnog planiranja razvoja } \\
\text { karijere oficira }\end{array}$ & 72 & 32.9 & 35 & 16.0 & 112 & 51.1 & 219 & 100 \\
\hline
\end{tabular}

Odgovori na pitanje „Da li normativno-pravne pretpostavke u dovoljnoj meri čine proces razvoja karijere oficira predvidivim“, ukazuju na to da skoro polovina ispitanika „ne zna" da li normativno-pravne pretpostavke čine ovaj proces predvidivim $(48,4 \%)$. Nešto manje od jedne trećine ispitanika dalo je pozitivan odgovor na ovo pitanje $(31,1 \%)$. Međutim, nešto veći procenat ispitanika se izjasnio u prilog uticaja „Odredbi Zakona o Vojsci Srbije na pravilan i ravnomeran razvoj karijere oficira". Naime, skoro 40 osto ispitanika $(38,8 \%)$ se izjasnilo u prilog ovoj tvrdi, a polovina manje ispitanika $(17,8 \%)$ smatra da ovaj normativni dokument ne čini ovaj proces u dovoljnoj meri predvidivim. Oko 30 odsto ispitanika ocenjuje da „Godišnji plan školovanja i obuke u Ministarstvu odbrane predstavlja najvažniji dokument u sklopu individualnog planiranja razvoja karijere oficira“ $(32,9 \%)$. Polovina ispitanika je bila neodlučna $(50,7 \%)$, a blizu 20 odsto njih se negativno izrazilo po ovom pitanju.

Na kraju prvog dela analize rezultata deskriptivne statistike može se zaključiti da normativno-pravne pretpostavke ne obezbeđuju u značajnoj meri uspešan razvoj karijere oficira.

\section{Uticaj različitih subjekata upravljanja ljudskim resursima na razvoj karijere oficira}

U procesu razvoja karijere oficira aktivno učestvuje više subjekata, od oficira kao pojedinaca, preko pretpostavljenih starešina i komandi, do subjekata upravljanja ljudskim resursima na svim nivoima. Naravno, da se i sami oficiri izjašnjavaju o tome koji tip karijere najviše žele, a zatim se u odnosu na potrebe sistema odbrane određuje odgovarajući tip karijere. Reč je o sedam tipova karijere koji su razmatrani u ovom istraživanju: 1/komandno-operativna; 2/štabno-funkcionalna; 3/karijera u planiranju odbrane; 4/karijera ljudskih resursa; 5/logistička; 6/obaveštajno-bezbednosna i 7/naučno-nastavna karijera. U vezi s tim, postavljena su im pitanja koji je njihov željeni tip karijere.

$\mathrm{Na}$ osnovu podataka prikazanih u tabeli 2, najveći procenat željenih tipova karijera se odnosi na komandno-operativnu $(60,7 \%)$, a znatno manje na obaveštajno-bezbednosnu $(11,9)$ i štabno-funkcionalnu karijeru $(10,5 \%)$. Ostali tipovi karijere su poželjni u obimu manjim od pet procenata. 
Tabela 2 - Željeni tipovi karijere oficira

\begin{tabular}{|c|c|c|c|}
\hline Valid & Frekvencija & Procenat & Kumulativni procenat \\
\hline 1.00 & 133 & 60.7 & 60.7 \\
\hline 2.00 & 23 & 10.5 & 71.2 \\
\hline 3.00 & 10 & 4.6 & 75.8 \\
\hline 4.00 & 7 & 3.2 & 79.0 \\
\hline 5.00 & 9 & 4.1 & 83.1 \\
\hline 6.00 & 26 & 11.9 & 95.0 \\
\hline 7.00 & 11 & 5.0 & 100.0 \\
\hline Ukupno & 219 & 100.0 & \\
\hline
\end{tabular}

1/komandno-operativna; 2/štabno-funkcionalna; 3/karijera u planiranju odbrane; 4/karijera ljudskih resursa; 5/logistička; 6/obaveštajno-bezbednosna; 7/naučno-nastavna karijera

Ispitanici su se izjasnili i o tome koji su im tipovi karijere određeni. Prema podacima prikazanim u tabeli 3. uočljivo je da je najveći procenat ispitanika raspoređen na komandno-operativne dužnosti $(72,1 \%)$, a znatno manje na štabno-funkcionalne (10\%) i obaveštajno-bezbednosne funkcije (9,6\%). Ostali tipovi karijere su zastupljeni u znatno manjem procentu.

Tabela 3 - Tipovi karijere prema kojima su raspoređeni oficiri

\begin{tabular}{|c|c|c|c|}
\hline Valid & Frekvencija & Procenat & Kumulativni procenat \\
\hline 1.00 & 158 & 72.1 & 72.1 \\
2.00 & 22 & 10.0 & 82.2 \\
3.00 & 3 & 1.4 & 83.6 \\
4.00 & 5 & 2.3 & 85.8 \\
5.00 & 7 & 3.2 & 89.0 \\
6.00 & 21 & 9.6 & 98.6 \\
7.00 & 3 & 1.4 & 100.0 \\
Ukupno & 219 & 100.0 & \\
\hline
\end{tabular}

1/komandno-operativna; 2/štabno-funkcionalna; 3/karijera u planiranju odbrane; 4/karijera ljudskih resursa; 5/logistička; 6/obaveštajno-bezbednosna; 7/naučno-nastavna karijera

U nastojanju da utvrdimo koji subjekti najviše učestvuju u razvoju karijere oficira, ispitanicima je postavljeno istovetno pitanje. Rezultati istraživanja prikazani u tabeli 4, pokazali su da na razvoj karijere oficira najviše utiču pretpostavljene starešine (32,9\%), zatim pretpostavljene komande i štabovi $(31,1 \%)$, a tek onda lične želje i ambicija (26,5\%). Uticaj ostalih subjekata (Uprava za ljudske resurse GŠ VS; Uprava za kadrove MO i ostali faktori) je ispod 10 odsto $(9,6 \%)$.

Tabela 4 - Vrste subjekata koji imaju uticaj na razvoj karijere oficira 


\begin{tabular}{|c|c|c|c|}
\hline Valid & Frekvencija & Procenat & Kumulativni procenat \\
\hline 1.00 & 58 & 26.5 & 26.5 \\
\hline 2.00 & 72 & 32.9 & 59.4 \\
\hline 3.00 & 68 & 31.1 & 90.4 \\
\hline 4.00 & 4 & 1.8 & 92.2 \\
\hline 5.00 & 3 & 1.4 & 93.6 \\
\hline 6.00 & 14 & 6.4 & 100.0 \\
\hline Ukupno & 219 & 100.0 & \\
\hline
\end{tabular}

1)lične želje, rad i ambicija; 2/pretpostavljeni starešina; 3/pretpostavljene komande i štabovi; 4/Uprava za ljudske resurse (J-1) GŠ VS; 5/Uprava za kadrove SLjR MO i 6/Ostali faktori.

Uticaj pojedinih faktora upravljanja ljudskim resursima na razvoj karijere oficira razmatran je preko sledećih indikatora: 1) Pripadnost određenom rodu i službi može u značajnoj meri uticati na razvoj karijere oficira; 2) Raspoređivanje oficira po završetku školovanja/ usavršavanja u značajnoj meri utiče na dalji razvoj njihove karijere; 3) Socijalna mreža (grupisanje) u smislu geografskog porekla, rođačkih linija i slično u značajnoj meri utiču na razvoj karijere oficira i 4) Uprava za kadrove SLjR Ministarstva odbrane u dovoljnoj meri obezbeđuje potrebne informacije o mogućnostima za razvoj karijere oficira (tabela 5).

Tabela 5 - Uticaj različitih subjekata upravljanja ljudskim resursima na razvoj karijere oficira

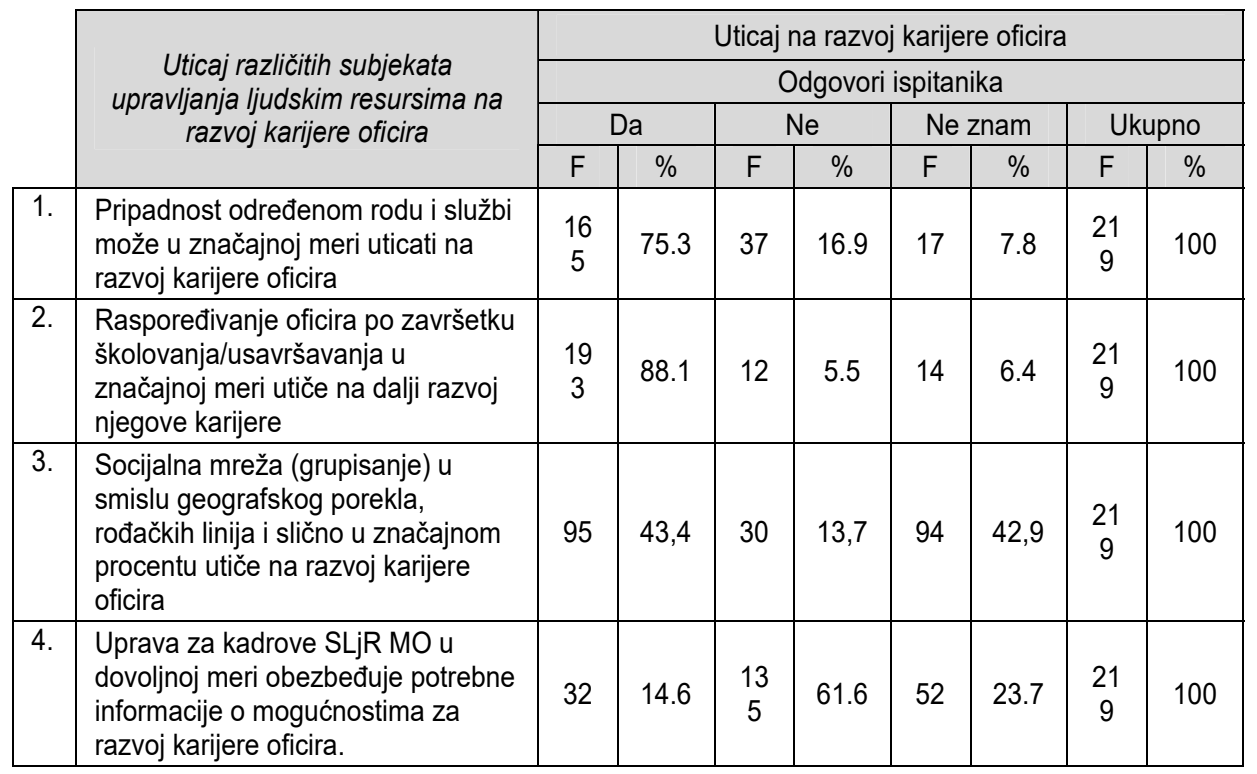


Odgovori na pitanje „Da li pripadnost određenom rodu-službi može u značajnoj meri da utiče na razvoj karijere oficira" ukazuju na to da čak 75,3 odsto ispitanika smatra da je pripadnost rodu-službi determinišući faktor za razvoj karijere oficira. Oko 17 odsto njih $(16,9 \%)$ smatra da to nije uticajni činilac, a oko 8 odsto ispitanika je neodlučno. Raspoređivanje oficira na dužnosti nakon završetka školovanja ima uticaja na razvoj karijere oficira. Rezultati istraživanja su pokazali da najveći procenat ispitanika smatra da je ovo vrlo značajan činilac za razvoj karijere oficira $(88,1 \%)$. Na raspoređivanje oficira nakon školovanja/usavršavanja utiču brojni faktori. Istraživanjem je potražen odgovor na pitanje „Da li socijalna mreža (grupisanje) u smislu geografskog porekla, rođačkih linija i slično u značajnom procentu utiče na razvoj karijere oficira?". Prema rezultatima istraživanja, skoro podjednak procenat ispitanika smatra da je to značajan činilac za razvoj karijere $(43,4 \%)$ i oko 43 odsto ispitanika je neodlučno po ovom pitanju $(42,9 \%)$, dok oko 14 odsto njih smatra da to nije odlučujući činilac za razvoj karijere oficira $(13,7 \%)$. Odgovori na pitanje „Da li Uprava za kadrove SLjR Ministarstva odbrane u dovoljnoj meri obezbeđuje potrebne informacije o mogućnostima za razvoj karijere oficira?", ukazuju na to da se preko 60 odsto ispitanika $(61,6 \%)$ izjasnilo u prilog tvrdnji da su te informacije nedovoljne za potpunu informisanost o mogućnostima razvoja karijere oficira, a svega oko 15 odsto ispitanika je saglasno sa ovom tvrdnjom.

Nakon sprovedene analize statističkih pokazatelja može se zaključiti da u procesu razvoja karijere oficira u različitoj meri učestvuje više subjekata, pri čemu raspoređivanje oficira nakon završetka školovanja/usavršavanja ima primarni značaj.

\section{Mere uspešnosti razvoja karijere oficira}

Uspešnost procesa razvoja karijere oficira zavisi od uspešnosti realizacije procesa planiranja, selekcije, školovanja, usavršavanja i raspoređivanja na odgovarajuće dužnosti. Shodno tome, mere uspešnosti razvoja karijere oficira razmatrane su putem sledećih indikatora: 1) Uspešnost razvoja karijere oficira umnogome zavisi od kvalitetnog planiranja razvoja starešinskog kadra; 2) Pravilna selekcija oficira za upućivanje na školovanje/usavršavanje predstavlja osnovni preduslov za uspešnost u razvoju njihove karijere; 3) Raspoređivanje oficira na dužnost nakon završetka usavršavanja trebalo bi da se prvenstveno obavlja na osnovu postignutog uspeha tokom usavršavanja; 4) Pravilan razvoj karijere oficira podrazumeva ne samo pomeranje oficira (u hijerarhiji VS/MO) po vertikali, već i po horizontali, čime se stiču dodatne stručne kompetencije; 5) U cilju pravilnog razvoja karijere, oficir bi trebao tokom radnog veka da se najmanje jednom (a poželjno i više puta) premešta iz Vojske Srbije u Ministarstvo odbrane, i obrnuto i 6) U toku profesionalne karijere, oficiri na najvišim dužnostima u Vojsci Srbije trebalo bi da provedu izvesno vreme na odgovarajućim nivoima visokoškolskog obrazovanja u ulozi nastavnika.

Deskriptivna analiza mera uspešnosti razvoja karijere oficira prema određenim indikatorima prikazana je u tabeli 6 . Uspešnost razvoja karijere oficira zavisi od uspešnosti procesa planiranja, selekcije, školovanja, usavršavanja i raspoređivanja na odgovarajuće dužnosti oficira. Prvi korak u tom procesu je kvalitetni proces planiranja razvoja oficirskog kadra. Rezultati istraživanja su pokazali da oko 70 odsto ispitanika $(71,7 \%)$ smatra da uspešnost razvoja karijere oficira umnogome zavisi od kvalitetnog planiranja razvoja starešinskog kadra. 
Tabela 6 - Mere uspešnosti razvoja karijere oficira

\begin{tabular}{|c|c|c|c|c|c|c|c|c|c|}
\hline & \multirow{4}{*}{$\begin{array}{c}\text { Mere uspešnosti razvoja } \\
\text { karijere oficira }\end{array}$} & \multicolumn{8}{|c|}{ Uticaj na razvoj karijere oficira } \\
\hline & & \multicolumn{8}{|c|}{ Odgovori ispitanika } \\
\hline & & \multicolumn{2}{|c|}{$\mathrm{Da}$} & \multicolumn{2}{|c|}{$\mathrm{Ne}$} & \multicolumn{2}{|c|}{ Ne znam } & \multicolumn{2}{|c|}{ Ukupno } \\
\hline & & $\mathrm{F}$ & $\%$ & $\mathrm{~F}$ & $\%$ & $\mathrm{~F}$ & $\%$ & $\mathrm{~F}$ & $\%$ \\
\hline 1. & $\begin{array}{l}\text { Uspešnost razvoja karijere oficira } \\
\text { umnogome zavisi od kvalitetnog } \\
\text { planiranja razvoja starešinskog } \\
\text { kadra }\end{array}$ & $\begin{array}{c}15 \\
7\end{array}$ & 71.7 & 25 & 11.4 & 37 & 16.9 & $\begin{array}{c}21 \\
9\end{array}$ & 100 \\
\hline 2. & $\begin{array}{l}\text { Pravilna selekcija oficira za } \\
\text { upućivanje na } \\
\text { školovanja/usavršavanja } \\
\text { predstavlja osnovni preduslov za } \\
\text { uspešnost u razvoju njihove karijere }\end{array}$ & $\begin{array}{c}18 \\
3\end{array}$ & 83.6 & 21 & 9.6 & 15 & 6.8 & $\begin{array}{c}21 \\
9\end{array}$ & 100 \\
\hline 3. & $\begin{array}{l}\text { Raspoređivanje oficira na dužnost } \\
\text { nakon završetka usavršavanja } \\
\text { trebalo bi da se prvenstveno } \\
\text { obavlja na osnovu postignutog } \\
\text { uspeha tokom usavršavanja }\end{array}$ & $\begin{array}{c}11 \\
0\end{array}$ & 50.2 & 91 & 41.6 & 18 & 8.2 & $\begin{array}{c}21 \\
9\end{array}$ & 100 \\
\hline 4. & $\begin{array}{l}\text { Pravilan razvoj karijere } \\
\text { podrazumeva ne samo pomeranje } \\
\text { oficira (u hijerarhiji VS/MO) po } \\
\text { vertikali, već i po horizontali, čime } \\
\text { se stiču dodatne stručne } \\
\text { kompetencije }\end{array}$ & $\begin{array}{c}18 \\
6\end{array}$ & 84.9 & 15 & 6.8 & 18 & 8.2 & $\begin{array}{c}21 \\
9\end{array}$ & 100 \\
\hline 5. & $\begin{array}{l}\text { U cilju pravilnog razvoja karijere, } \\
\text { oficir bi trebao tokom radnog veka } \\
\text { da se najmanje jednom (a poželjno } \\
\text { i više puta) premešta iz Vojske } \\
\text { Srbije u Ministarstvo odbrane, i } \\
\text { obrnuto }\end{array}$ & $\begin{array}{c}12 \\
3\end{array}$ & 56.2 & 57 & 26.0 & 39 & 17.8 & $\begin{array}{c}21 \\
9\end{array}$ & 100 \\
\hline 6. & $\begin{array}{l}\text { U toku profesionalne karijere, oficiri } \\
\text { na najvišim dužnostima u Vojsci } \\
\text { Srbije trebalo bi da provedu izvesno } \\
\text { vreme na odgovarajućim nivoima } \\
\text { visokoškolskog obrazovanja u ulozi } \\
\text { nastavnika }\end{array}$ & $\begin{array}{c}10 \\
8\end{array}$ & 49.3 & 62 & 28.3 & 49 & 22.4 & $\begin{array}{c}21 \\
9\end{array}$ & 100 \\
\hline
\end{tabular}

Drugi korak u razvoju karijere oficira predstavlja selekcija oficirskog kadra za proces njihovog školovanja/usavršavanja. Prema rezultatima istraživanja, preko 80 odsto ispitanika $(83,6 \%)$ smatra da pravilna selekcija oficira za upućivanje na školovanje/usavršavanje predstavlja osnovni preduslov za uspešnost u razvoju karijere oficira. Treći korak u razvoju karijere oficira predstavlja njihovo osposobljavanje za obavljanje dužnosti, a četvrti korak čini njihovo raspoređivanje na dužnosti za koje su osposobljeni. Kao obavezna etapa u razvoju karijere oficira javlja se usavršavanje oficira koje se odvija na različitim nivoima. I nakon tog procesa obavlja se raspoređivanje oficira na dužnosti za koje su se usavršavali. U vezi s tim, ispitanicima je postavljeno pitanje: „Da li raspoređivanje oficira na dužnost nakon usavršavanja trebalo bi da se prvenstveno obavlja na osnovu postignutog uspeha tokom usavršava- 
nja?" Oko 50 odsto ispitanika se slaže s ovom tvrdnjom, s tim da čak 40 odsto njih smatra da to ne bi trebalo da bude pravilo. Dakle, mišljenje po ovom pitanju je skoro podeljeno. U vojnoj profesiji, razvoj karijere oficira podrazumeva horizontalno i vertikalno pomeranje u toku profesije. Kada je reč o horizontalnom pomeranju oficira, smatra se da ono obezbeđuje dodatne stručne kompetencije. Ispitanici su se u većini složili s ovom tvrdnjom (84,9\%), a svega 8,2 odsto njih je izrazilo negativan stav po ovom pitanju. Preko 50 odsto ispitanika $(56,2 \%)$ se izjasnilo da bi oficiri trebali da se tokom radnog veka najmanje jednom premeštaju iz Vojske Srbije u Ministarstvo odbrane, i obrnuto. Osim toga, istraživački podaci ukazuju na to da oko 50 odsto ispitanika smatra da bi oficiri tokom profesionalne karijere trebali da provedu izvesno vreme u vojnoškolskim ustanovama na nastavničkim dužnostima.

$\mathrm{Na}$ osnovu prezentovanih rezultata istraživanja može se zaključiti da uspešnost procesa razvoja karijere oficira u značajnoj meri zavisi od uspešnosti realizacije procesa planiranja, selekcije, školovanja, usavršavanja i raspoređivanja na odgovarajuće dužnosti.

\section{Efekti pravilnog razvoja karijere oficira}

Efekti pravilno sprovedenog procesa razvoja karijere oficira su višestruki, a u ovom radu su sagledani putem sledećih indikatora: 1) Efekti pravilnog razvoja karijere oficira značajno doprinose optimalnoj iskorišćenosti ljudskih i materijalnih resursa njihovih jedinica; 2) Pravilnim razvojem karijere oficira, obezbeđuje se da u jedinicama/ustanovama Vojske Srbije komanduju/rukovode najsposobniji i najkompetentniji oficiri; 3) Efekti pravilnog razvoja karijere oficira neposredno utiču na motivisanost starešinskog kadra za postizanje odličnih rezultata na formacijskoj dužnosti; 4) Pravilan razvoj karijere oficira umnogome utiče na motivisanost starešinskog kadra za profesionalnim razvojem u struci (obrazovanje tokom života) i 5) Efekti pravilnog razvoja karijere oficira neposredno utiču na razvoj i održavanje operativnih sposobnosti njihovih jedinica, kao i Vojske Srbije u celini.

Pravilan razvoj karijere oficira ima značajne praktične implikacije koje se ogledaju, pre svega, u efektivnoj iskorišćenosti ljudskih i materijalnih potencijala vojnoorganizacionih jedinica kojima rukovode. U prilog ovoj tvrdnji mogu da posluže rezultati istraživanja koji su prikazani u tabeli 7 .

Tabela 7 - Efekti pravilnog razvoja karijere oficira

\begin{tabular}{|c|c|c|c|c|c|c|c|c|c|}
\hline & \multirow{4}{*}{$\begin{array}{l}\text { Efekti pravilnog razvoja } \\
\text { karijere oficira }\end{array}$} & \multicolumn{8}{|c|}{ Uticaj na razvoj karijere oficira } \\
\hline & & \multicolumn{8}{|c|}{ Odgovori ispitanika } \\
\hline & & \multicolumn{2}{|c|}{$\mathrm{Da}$} & \multicolumn{2}{|c|}{$\mathrm{Ne}$} & \multicolumn{2}{|c|}{ Ne znam } & \multicolumn{2}{|c|}{ Ukupno } \\
\hline & & $\mathrm{F}$ & $\%$ & $F$ & $\%$ & $\mathrm{~F}$ & $\%$ & $\mathrm{~F}$ & $\%$ \\
\hline 1. & $\begin{array}{l}\text { Efekti pravilnog razvoja karijere } \\
\text { oficira značajno doprinose } \\
\text { optimalnoj iskorišćenosti ljudskih i } \\
\text { materijalnih resursa njihovih } \\
\text { jedinica }\end{array}$ & $\begin{array}{c}17 \\
0\end{array}$ & 77.6 & 18 & 8.2 & 31 & 14.2 & $\begin{array}{c}21 \\
9\end{array}$ & 100 \\
\hline 2. & $\begin{array}{l}\text { Pravilnim razvojem karijere oficira, } \\
\text { obezbeđuje se da u } \\
\text { jedinicama/ustanovama Vojske } \\
\text { Srbije komanduju/rukovode } \\
\text { najsposobniji i najkompetentniji oficiri }\end{array}$ & $\begin{array}{c}17 \\
9\end{array}$ & 81.7 & 27 & 12.3 & 13 & 5.9 & $\begin{array}{c}21 \\
9\end{array}$ & 100 \\
\hline
\end{tabular}




\begin{tabular}{|c|l|c|c|c|c|c|c|c|c|}
\hline 3. & $\begin{array}{l}\text { Efekti pravilnog razvoja karijere } \\
\text { oficira neposredno utiču na } \\
\text { motivisanost starešinskog kadra za } \\
\text { postizanje odličnih rezultata na } \\
\text { formacijskoj dužnosti }\end{array}$ & $\begin{array}{c}20 \\
3\end{array}$ & 92.7 & 8 & 3.7 & 8 & 3.7 & $\begin{array}{c}21 \\
9\end{array}$ & 100 \\
\hline 4. & $\begin{array}{l}\text { Pravilan razvoj karijere oficira } \\
\text { umnogome utiče na motivisanost } \\
\text { starešinskog kadra za } \\
\text { profesionalnim razvojem u struci } \\
\text { (obrazovanje tokom života) }\end{array}$ & $\begin{array}{c}18 \\
5\end{array}$ & 84.5 & 8 & 3.7 & 26 & 11.9 & $\begin{array}{c}21 \\
9\end{array}$ & 100 \\
\hline 5. & $\begin{array}{l}\text { Efekti pravilnog razvoja karijere } \\
\text { oficira neposredno utiču na razvoj } \\
\text { karijere oficira }\end{array}$ & $\begin{array}{c}19 \\
8\end{array}$ & 90.4 & 7 & 3.2 & 14 & 6.4 & $\begin{array}{c}21 \\
9\end{array}$ & 100 \\
\hline
\end{tabular}

Ovi rezultati pokazuju da 77,6 odsto ispitanika smatra da efekti pravilnog razvoja karijere oficira doprinose optimalnoj iskorišćenosti ljudskih i materijalnih potencijala, a svega 8,2 odsto njih se ne slaže s ovom tvrdnjom. Ovoj grupi ispitanika treba dodati 14,2 odsto neodlučnih ispitanika. U visokom procentu se ispitanici izjašnjavaju da efekti pravilnog razvoja oficira doprinose da jedinicama/ustanovama Vojske Srbije komanduju/rukovode najsposobniji i najkompetentniji oficiri $(81,7 \%)$, dok 12,3 odsto njih se ne slaže s ovom tvrdnjom. Još veći procenat ispitanika se izjasnio u prilog tvrdnji da pravilan razvoj karijere oficira neposredno utiče na motivisanost starešinskog kadra za postizanje odličnih rezultata $(92,7 \%)$, a svega 7,3 odsto njih se nije složilo s ovom tvrdnjom. Takođe, veliki procenat ispitanika se slaže s tvrdnjom da pravilan razvoj karijere oficira utiče na motivisanost oficirskog kadra za profesionalnim razvojem u struci (84,5\%), a 12 odsto ispitanika se nije složilo po ovom pitanju. Najveći procenat ispitanika se izjasnio u prilog tvrdnji da efekti pravilnog razvoja karijere oficira utiču na razvoj $i$ održavanje operativnih sposobnosti jedinica-ustanova kojima rukovode (90,4\%), a svega 9,6 odsto ispitanika se nije pozitivno izjasnilo po ovom pitanju.

$\mathrm{Na}$ osnovu analize statističkih pokazatelja (deskriptivne statistike) može se zaključiti da su efekti pravilno sprovedenog procesa razvoja karijere oficira višestruki i ogledaju se u efektivnoj iskorišćenosti ljudskih potencijala jedinice, što u značajnoj meri utiče na razvoj o održavanje operativnih sposobnosti njihovih jedinica i Vojske Srbije u celini.

\section{Razlike u procenama uticaja različitih činilaca na profesionalni razvoj karijere oficira}

Razlike u procenama uticaja različitih činilaca na profesionalni razvoj karijere oficira razmatrani su putem analize razlika u proceni uticaja normativno-pravnih pretpostavki na uspešnost razvoja karijere oficira, razlika u proceni uticaja različitih subjekata upravljanja ljudskim resursima na uspešnost razvoja karijere oficira; razlika u proceni uticaja uspešnosti realizacije procesa planiranja, selekcije, školovanja, usavršavanja i raspoređivanja na odgovarajuće dužnosti i razlike u proceni efekata pravilnog razvoja karijere oficira 


\section{Razlike u proceni uticaja normativno-pravnih pretpostavki}

\section{na uspešnost razvoja karijere oficira}

Procena uticaja normativno-pravnih pretpostavki na razvoj karijere oficira uslovljena je brojnim personalnim, statusnim i andragoškim obeležjima ispitanika, a najviše sa njihovom „starošću“, „činom“ i „najvišim vojnim usavršavanjem“. Ovo ispitivanje je obavljeno pomoću analize varijanse.

Kad je u pitanju varijabla "starost" utvrđena je značajna razlika među grupama ispitanika (1/do 35 godina; 2/35-40 godina; 3/40-45 godina; 4/preko 45 godina) po pitanju tri indikatora: 1) „Ponovno uvođenje polaganja ispita za čin majora bi unapredilo proces razvoja karijere oficira“ ( $F=8,893 ; p=0,000) ; 2)$ „Normativno-pravne pretpostavke čine proces razvoja karijere oficira u dovoljnoj meri predvidivim“ ( $F=5,155 ; p=0,002)$ i 3) „Odredbe Zakona o Vojsci Srbije omogućavaju pravilan i ravnomeran razvoj karijere oficira" $(F=4,910 ; p=0,003)$ (tabela 8).

Tabela 8 - Rezultati analiza varijanse - varijabla „starost“

\begin{tabular}{|c|c|c|c|c|c|c|}
\hline & & $\begin{array}{c}\text { Sume } \\
\text { kvadriranih } \\
\text { odstupanja }\end{array}$ & $\begin{array}{c}\text { Broj } \\
\text { stepeni } \\
\text { slobode }\end{array}$ & $\begin{array}{c}\text { Ocene varijansi } \\
\text { između i unutar } \\
\text { grupa }\end{array}$ & F statistik & $\begin{array}{c}\text { Nivo } \\
\text { značajnosti }\end{array}$ \\
\hline \multirow[t]{3}{*}{ UREDBA } & Između grupa & 1.465 & 3 & \multirow{3}{*}{$\begin{array}{l}.488 \\
.583\end{array}$} & \multirow[t]{3}{*}{.838} & \multirow[t]{3}{*}{.474} \\
\hline & Unutar grupa & 125.284 & 215 & & & \\
\hline & Ukupno & 126.749 & 218 & & & \\
\hline \multirow[t]{3}{*}{ ISPCINMAJ } & Između grupa & 16.901 & 3 & \multirow{3}{*}{$\begin{array}{r}.634 \\
.634\end{array}$} & \multirow[t]{3}{*}{8.893} & \multirow[t]{3}{*}{.000} \\
\hline & Unutar grupa & 136.204 & 215 & & & \\
\hline & Ukupno & 153.105 & 218 & & & \\
\hline \multirow[t]{3}{*}{ NORMERAZK } & Između grupa & 11.233 & 3 & \multirow{3}{*}{$\begin{array}{r}.744 \\
.726\end{array}$} & \multirow[t]{3}{*}{5.155} & \multirow[t]{3}{*}{.002} \\
\hline & Unutar grupa & 156.173 & 215 & & & \\
\hline & Ukupno & 167.406 & 218 & & & \\
\hline \multirow[t]{3}{*}{ ZAKONVSRK } & Između grupa & 11.513 & 3 & \multirow{3}{*}{$\begin{array}{r}.838 \\
.782\end{array}$} & \multirow[t]{3}{*}{4.910} & \multirow[t]{3}{*}{.003} \\
\hline & Unutar grupa & 168.030 & 215 & & & \\
\hline & Ukupno & 179.543 & 218 & & & \\
\hline \multirow[t]{3}{*}{ GODPLSKOL } & Između grupa & 2.225 & 3 & \multirow{3}{*}{$\begin{array}{l}.742 \\
.876\end{array}$} & \multirow[t]{3}{*}{.847} & \multirow[t]{3}{*}{.470} \\
\hline & Unutar grupa & 188.332 & 215 & & & \\
\hline & Ukupno & 190.557 & 218 & & & \\
\hline
\end{tabular}

UREDBA („Uredba o stanjima u službi i unapređivanju oficira, podoficira i profesionalnih vojnika“); ISPCINMAJ („Ponovno uvođenje polaganja ispita za čin majora bi unapredilo proces razvoja karijere oficira“); NORMERAZK („Normativno-pravne pretpostavke čine proces razvoja oficira predvidljivim u dovoljnoj meri "); ZAKONVSRK („Od- 
redbe Zakona o Vojsci Srbije omogućavaju pravilan i ravnomeran razvoj karijere oficira“); GODPLSKOL („Godišnji plan školovanja i obuke u Ministarstvu odbrane predstavlja najvažniji dokument u sklopu individualnog planiranja razvoja karijere oficir").

Prilikom razmatranja statusnog obeležja „čina“ utvrđene su takođe značajne razlike među grupama ispitanika (1/poručnik; 2/kapetan; 3/major; 4/potpukovnik; 5/pukovnik) za tri indikatora: 1) „Ponovno uvođenje polaganja ispita za čin majora bi unapredilo proces razvoja karijere oficira“ ( $F=9,339 ; p=0,000) ; 2)$ „Normativno-pravne pretpostavke čine proces razvoja oficira predvidivim u dovoljnoj meri“ $(F=3,845 ; p=0,005)$ i 3$)$ „Odredbe Zakona o Vojsci Srbije omogućuju pravilan i ravnomeran razvoj karijere oficira" ( $F=4,857$; $\mathrm{p}=0,001$ ) (tabela 9).

Tabela 9 - Rezultati analiza varijanse - varijabla „čin“

\begin{tabular}{|c|c|c|c|c|c|c|}
\hline & & $\begin{array}{c}\text { Sume } \\
\text { kvadriranih } \\
\text { odstupanja }\end{array}$ & $\begin{array}{c}\text { Broj stepeni } \\
\text { slobode }\end{array}$ & $\begin{array}{c}\text { Ocene varijansi } \\
\text { između i unutar } \\
\text { grupa }\end{array}$ & F statistik & $\begin{array}{c}\text { Nivo } \\
\text { značajnosti }\end{array}$ \\
\hline \multirow[t]{3}{*}{ UREDBA } & Između grupa & 4.477 & 4 & \multirow{3}{*}{$\begin{array}{r}1.119 \\
.571\end{array}$} & \multirow[t]{3}{*}{1.959} & \multirow[t]{3}{*}{.102} \\
\hline & Unutar grupa & 122.271 & 214 & & & \\
\hline & Ukupno & 126.749 & 218 & & & \\
\hline \multirow[t]{3}{*}{ ISPCINMAJ } & Između grupa & 22.753 & 4 & \multirow{3}{*}{$\begin{array}{r}5.688 \\
.609\end{array}$} & \multirow[t]{3}{*}{9.339} & \multirow[t]{3}{*}{.000} \\
\hline & Unutar grupa & 130.352 & 214 & & & \\
\hline & Ukupno & 153.105 & 218 & & & \\
\hline \multirow[t]{3}{*}{ NORMERAZK } & Između grupa & 11.224 & 4 & \multirow{3}{*}{$\begin{array}{r}2.806 \\
.730\end{array}$} & \multirow[t]{3}{*}{3.845} & \multirow[t]{3}{*}{.005} \\
\hline & Unutar grupa & 156.182 & 214 & & & \\
\hline & Ukupno & 167.406 & 218 & & & \\
\hline \multirow[t]{3}{*}{ ZAKONVSRK } & Između grupa & 14.942 & 4 & \multirow{3}{*}{$\begin{array}{r}3.735 \\
.769\end{array}$} & \multirow[t]{3}{*}{4.857} & \multirow[t]{3}{*}{.001} \\
\hline & Unutar grupa & 164.601 & 214 & & & \\
\hline & Ukupno & 179.543 & 218 & & & \\
\hline \multirow[t]{3}{*}{ GODPLSKOL } & Između grupa & 8.056 & 4 & \multirow{3}{*}{$\begin{array}{r}2.014 \\
.853\end{array}$} & \multirow[t]{3}{*}{2.361} & \multirow[t]{3}{*}{.054} \\
\hline & Unutar grupa & 182.502 & 214 & & & \\
\hline & Ukupno & 190.557 & 218 & & & \\
\hline
\end{tabular}

UREDBA („Uredba o stanjima u službi i unapređivanju oficira, podoficira i profesionalnih vojnika potpunosti omogućava uslove za adekvatan razvoj karijere oficira"); ISPCINMAJ („Ponovno uvođenje polaganja ispita za čin majora bi unapredilo process razvoja karijere oficira“); NORMERAZK („Normativno-pravne pretpostavke čine proces razvoja oficira predvidljivim u dovoljnoj meri“); ZAKONVSRK („Odredbe Zakona o Vojsci Srbije omogućuju pravilan i ravnomeran razvoj karijere oficira“); GODPLSKOL („Godišnji plan školovanja i obuke u Ministarstvu odbrane predstavlja najvažniji dokument u sklopu individualnog planiranja razvoja karijere oficira"). 
$U$ istraživanju je utvrđena značajna razlika među grupama ispitanika po pitanju varijable „najviše vojno usavršavanje“ (1/komandno-štabno usavršavanje; 2/generalštabno usavršavanje; 3)osnovni komandno-štabni kurs i 4/ostalo) za četiri indikatora: 1) „Uredba o stanjima u službi i unapređivanju oficira, podoficira i profesionalnih vojnika u potpunosti omogućava uslove za adekvatan razvoj karijere oficira“ ( $F=3,002 ; p=0,031) ; 2)$ „Ponovno uvođenje polaganja ispita za čin majora bi unapredilo proces razvoja karijere oficira" $(F=9,741 ; p=0,000) ; 3)$ „Normativno-pravne pretpostavke čine proces razvoja oficira u dovoljnoj meri predvidivim“ ( $F=3,717 ; p=0,012)$ i 4) "Odredbe Zakona o Vojsci Srbije omogućuju pravilan i ravnomeran razvoj karijere oficira" $(F=3,117 ; p=0,027)$ (tabela 10).

Tabela 10 - Rezultati analiza varijanse - varijabla „najviše vojno usavršavanje“

\begin{tabular}{|c|c|c|c|c|c|c|}
\hline & & $\begin{array}{c}\text { Sume } \\
\text { kvadriranih } \\
\text { odstupanja }\end{array}$ & $\begin{array}{c}\text { Broj } \\
\text { stepeni } \\
\text { slobode }\end{array}$ & $\begin{array}{c}\text { Ocene varijansi } \\
\text { između i unutar } \\
\text { grupa }\end{array}$ & F statistik & $\begin{array}{c}\text { Nivo } \\
\text { značajnosti }\end{array}$ \\
\hline \multirow[t]{3}{*}{ UREDBA } & Između grupa & 5.096 & 3 & 1.699 & 3.002 & .031 \\
\hline & Unutar grupa & 121.653 & 215 & .566 & & \\
\hline & Ukupno & 126.749 & 218 & & & \\
\hline \multirow[t]{3}{*}{ ISPCINMAJ } & Između grupa & 18.320 & 3 & 6.107 & 9.741 & .000 \\
\hline & Unutar grupa & 134.785 & 215 & .627 & & \\
\hline & Ukupno & 153.105 & 218 & & & \\
\hline \multirow[t]{3}{*}{ NORMERAZK } & Između grupa & 8.254 & 3 & 2.751 & 3.717 & .012 \\
\hline & Unutar grupa & 159.153 & 215 & .740 & & \\
\hline & Ukupno & 167.406 & 218 & & & \\
\hline \multirow[t]{3}{*}{ ZAKONVSRK } & Između grupa & 7.483 & 3 & 2.494 & 3.117 & .027 \\
\hline & Unutar grupa & 172.060 & 215 & .800 & & \\
\hline & Ukupno & 179.543 & 218 & & & \\
\hline \multirow[t]{3}{*}{ GODPLSKOL } & Između grupa & 4.097 & 3 & 1.366 & 1.575 & .196 \\
\hline & Unutar grupa & 186.460 & 215 & .867 & & \\
\hline & Ukupno & 190.557 & 218 & & & \\
\hline
\end{tabular}

UREDBA („Uredba o stanjima u službi i unapređivanju oficira, podoficira i profesionalnih vojnika u potpunosti omogućava uslove za adekvatan razvoj karijere oficira"); ISPCINMAJ („Ponovno uvođenje polaganja ispita za čin majora bi unapredilo proces razvoja karijere oficira“); NORMERAZK („Normativno-pravne pretpostavke čine proces razvoja oficira predvidljivim u dovoljnoj meri“); ZAKONVSRK („Odredbe Zakona o Vojsci Srbije omogućuju pravilan i ravnomeran razvoj karijere oficira“); GODPLSKOL („Godišnji plan školovanja i obuke u Ministarstvu odbrane predstavlja najvažniji dokument u sklopu individualnog planiranja razvoja karijere oficira").

Značajna razlika među grupama ispitanika je utvrđena i kod varijable „penzijski staž“ (1/do 10 godina; 2/11-20 godina; 3/21-30 godina; 4/preko 30 godina) za dva indikatora: 
1) „Ponovno uvođenje polaganja ispita za čin majora bi unapredilo proces razvoja karijere oficira“ ( $F=6,297 ; p=0,000)$ i 2$)$ „Normativno-pravne pretpostavke čine proces razvoja karijere oficira u dovoljnoj meri predvidivim" ( $F=3,502 ; p=0,016)$.

Jedna značajna razlika među grupama ispitanika je utvrđena za varijablu „dužnost“ (1/komandna; 2/rukovodeća; 3/ostale) i za jedan indikator: „Ponovno uvođenje polaganja ispita za čin majora bi unapredilo proces razvoja karijere oficira" ( $F=4,749 ; p=0,010)$. Ovakva razlika je postignuta i za varijablu „poslednja službena ocena“ (1/2,50-3,00; 2/3,01-3,50; $3 / 3,51-4,00 ; 4 / 4,01-4,50 ; 4,51-5,00)$ i to za isti indikator: „Ponovno uvođenje polaganja ispita za čin majora bi unapredilo proces razvoja karijere oficira" ( $F=5,872 ; p=0,003)$. U odnosu na varijablu „stepen obrazovanja“ (1/visoko; 2/master; 3/specijalizacija; 4/magistar; 5/doktor nauka) utvrđena je jedna značajna razlika među grupama ispitanika po osnovi indikatora „Odredbe Zakona o Vojsci Srbije omogućuju pravilan i ravnomeran razvoj karijere oficira“ ( $F=2,744 ; p=0,044)$. Korišćenjem varijable „najviše vojno obrazovanje“ (1/vojna gimnazija ili srednja vojna škola; 2/vojna akademija; 3/specijalizacija 4/ magisterijum; 5/doktorat) utvrđena je jedna značajna razlika među grupama u odnosu na jedan indikator „Odredbe Zakona o Vojsci Srbije' omogućuju pravilan i ravnomeran razvoj karijere oficira“ ( $F=3,406 ; p=0,010)$. Takođe, jedna značajna razlika među grupama je utvrđena i u odnosu na varijablu „Da li je poznavanje stranog jezika uticalo na karijeru ispitanika?" (1/jesu, u velikoj meri; $2 /$ jeste, delimično; 3/nije; 4/ne znam) i to za sledeći indikator: „Ponovno uvođenje polaganja ispita za čin majora bi unapredilo proces razvoja karijere oficira" ( $F=2,795 ; p=0,041)$.

\section{Razlike u proceni uticaja različitih subjekata upravljanja ljudskim resursima na uspešnost razvoja karijere oficira}

Procena uticaja različitih subjekata upravljanja ljudskim resursima na razvoj karijere oficira determinisana je brojnim personalnim, statusnim i andragoškim obeležjima ispitanika, što je utvrđeno pomoću analize varijanse. Rezultati istraživanja su pokazali da su na taj proces najviše uticali sledeća personalna, statusna i andragoška obeležja: „čin " i „najviše vojno usavršavanje“.

Kad je u pitanju varijabla „čin" utvrđena je razlika među grupama ispitanika (1/poručnik; 2/kapetan; 3/major; 4/potpukovnik; 5/pukovnik) po pitanju dva indikatora: 1) „Na razvoj karijere oficira utiču brojni subjekti“ $(F=6,033 ; p=0,000)$ i 2$)$ „Socijalna mreža (grupisanje) u smislu geografskog porekla, rođačkih linija i slično u značajnom procentu utiče na razvoj karijere oficira" ( $F=3,471 ; p=0,009)$ (tabela 11).

Tabela 11 - Rezultati analiza varinse - varijabla „čin“

\begin{tabular}{|rl|r|r|r|r|r|}
\hline & $\begin{array}{c}\text { Sume } \\
\text { kvadriranih } \\
\text { odstupanja }\end{array}$ & $\begin{array}{c}\text { Broj } \\
\text { stepeni } \\
\text { slobode }\end{array}$ & $\begin{array}{c}\text { Ocene varijansi } \\
\text { između i unutar } \\
\text { grupa }\end{array}$ & F statistik & $\begin{array}{c}\text { Nivo } \\
\text { značajnosti }\end{array}$ \\
\hline FAKRAZKAR & Između grupa & 36.639 & 4 & 9.160 & 6.033 & .000 \\
& Unutar grupa & 324.904 & 214 & 1.518 & & \\
& Ukupno & 361.543 & 218 & & & \\
\hline
\end{tabular}




\begin{tabular}{|ll|r|r|r|r|r|}
\hline PRIPRODUKAR & Između grupa & .463 & 4 & .116 & .304 & .875 \\
& Unutar grupa & 81.518 & 214 & .381 & & \\
& Ukupno & 81.982 & 218 & & & \\
\hline RASPRAZVOJK & Između grupa & .923 & 4 & .231 & .716 & .582 \\
& Unutar grupa & 69.022 & 214 & .323 & & \\
& Ukupno & 69.945 & 218 & & & \\
\hline FAKTRASPOR & Između grupa & 2.281 & 4 & .570 & .511 & .728 \\
& Unutar grupa & 238.714 & 214 & 1.115 & & \\
& Ukupno & 240.995 & 218 & & & \\
\hline SOCMREZA & Između grupa & 8.677 & 4 & 2.169 & 3.471 & .009 \\
& Unutar grupa & 133.743 & 214 & .625 & & \\
& Ukupno & 142.420 & 218 & & & .276 \\
\hline UPRAVA & Između grupa & 1.932 & 4 & .483 & 1.288 & \\
KADROVA & Unutar grupa & 80.241 & 214 & .375 & & \\
& Ukupno & 82.174 & 218 & & & \\
\hline
\end{tabular}

FAKRAZKAR („Na razvoj karijere oficira utiču brojni subjekti“); PRIPRODUKAR („Pripadnost određenom rodu-službi može u značajnoj meri uticati na razvoj karijere oficira"); RASPRAZVOJK („Raspoređivanje oficira po završetku školovanja/ usavršavanja u značajnoj meri utiče na dalji razvoj njihove karijere“); SOCMREZA („Socijalna mreža (grupisanje) u smislu geografskog porekla, rođačkih linija i slično u značajnom procentu utiče na razvoj karijere oficira“) i UPRAVA KADROVA („Uprava za kadrove SLjR Ministartva odbrane u dovoljnoj meri obezbeđuje potrebne informacije o mogućnostima za razvoj karijere oficira“).

I prilikom ispitivanja uticaja obeležja „najviše vojno usavršavanje“ utvrđene su značajne razlike među grupama ispitanika (1/komandno-štabno usavršavanje; 2/generalštabno usavršavanje; 3/osnovno komandnio-štabno usavršavanje i 4/ostali vidovi usavršavanja) po pitanju dva indikatora: 1) „Na razvoj karijere oficira utiču brojni subjekti“ ( $F=3,700 ; p=0,013)$ i 2) „Socijalna mreža (grupisanje) u smislu geografskog porekla, rođačkih linija i slično u značajnom procentu utiče na razvoj karijere oficira" $(F=5,722 ; p=0,001)$ (tabela 12).

Tabela 12 - Rezultati analiza varijanse- varijabla „najviše vojno usavršavanje“

\begin{tabular}{|ll|r|r|r|r|r|}
\hline & $\begin{array}{c}\text { Sume } \\
\text { kvadriranih } \\
\text { odstupanja }\end{array}$ & $\begin{array}{c}\text { Broj } \\
\text { stepeni } \\
\text { slobode }\end{array}$ & $\begin{array}{c}\text { Ocene varijansi } \\
\text { između i unutar } \\
\text { grupa }\end{array}$ & F statistik & $\begin{array}{c}\text { Nivo } \\
\text { značajnosti }\end{array}$ \\
\hline FAKRAZKAR & Između grupa & 17.749 & 3 & 5.916 & 3.700 & .013 \\
& Unutar grupa & 343.795 & 215 & 1.599 & & \\
& Ukupno & 361.543 & 218 & & & \\
\hline PRIPRODUKAR & Između grupa & .795 & 3 & .265 & .701 & .552 \\
& Unutar grupa & 81.187 & 215 & .378 & & \\
& Ukupno & 81.982 & 218 & & & \\
\hline
\end{tabular}




\begin{tabular}{|ll|r|r|r|r|r|}
\hline RASPRAZVOJK & Između grupa & 1.200 & 3 & .400 & 1.251 & .292 \\
& Unutar grupa & 68.745 & 215 & .320 & & \\
& Ukupno & 69.945 & 218 & & & \\
\hline FAKTRASPOR & Između grupa & 1.162 & 3 & .387 & .347 & .791 \\
& Unutar grupa & 239.834 & 215 & 1.116 & & \\
& Ukupno & 240.995 & 218 & & & \\
\hline SOCMREZA & Između grupa & 10.530 & 3 & 3.510 & 5.722 & .001 \\
& Unutar grupa & 131.890 & 215 & .613 & & \\
& Ukupno & 142.420 & 218 & & & .349 \\
\hline UPRAVA & Između grupa & 1.245 & 3 & .415 & 1.102 & \\
KADROVA & Unutar grupa & 80.929 & 215 & .376 & & \\
& Ukupno & 82.174 & 218 & & & \\
\hline
\end{tabular}

FAKRAZKAR („Na razvoj karijere oficira utiču različiti subjekti“); PRIPRODUKAR („Pripadnost određenom rodu-službi može u značajnoj meri uticati na razvoj karijere oficira"); RASPRAZVOJK („Raspoređivanje oficira po završetku školovanja/usavršavanja u značajnoj meri utiče na dalji razvoj njegove karijere“); FAKTRASPOR („Na raspoređivanje oficira nakon završetka školovanja/usavršavanja u najvećoj meri utiču različiti faktori“); SOCMREZA („Socijalna mreža (grupisanje) u smislu geografskog porekla, rođačkih linija i slično u značajnom procentu utiče na razvoj karijere oficira"); UPRAVA KADROVA ('Uprava za kadrove SLjR MO u dovoljnoj meri obezbeđuje potrebne informacije o mogućnostima za razvoj karijere oficira");

Jedna značajna razlika među grupama ispitanika po osnovi procene uticaja različitih subjekata na profesionalni razvoj oficira utvrđena je u odnosu na sledeće varijable: 1) varijabla „starost“ (1/do 35 godina; 2/35-40 godina; 3/40-45 godina; 4/preko 45 godina) i za indikator: „Na razvoj karijere oficira utiču brojni faktori“ ( $F=4,905 ; p=0,003) ; 2)$ varijabla „penzijski staž" (1/do 10 godina; 2/11-20 godina; 3/21-30 godina; 4/preko 30 godina) i za indikator: „Na razvoj karijere oficira utiču brojni faktori“ ( $F=4,828 ; p=0,003) ; 3)$ varijabla „pripadnost određenom rodu-službi“ (1/pešadija; 2/artiljerija; 3/OMJ; 4/inžinjerija; 5/rečne jedinice; 6/ARJ PVD; 7NOJ; 8/tehnička; 9/saobraćajna; 10/intendantska; 11)telekomunikacije; 12/informatika; 13/El i PED; 14/avijacija; 15/finansijska služba; 16/personalna služba; 17/vojna policija; 18/sanitetska služba; 19/služba bezbednosti) i za indikator: „Socijalna mreža (grupisanje) u smislu geografskog porekla, rođačkih linija i slično u značajnom procentu utiče na razvoj karijere oficira" ( $F=1,780 ; p=0,030)$; 4) varijabla „poslednja službena ocena" $(1 / 2,50-3,00 ; 2 / 3,01-3,50 ; 3 / 3,51-4,00 ; 4 / 4,01-4,50 ; 4,51-5,00)$ i za indikator: „Raspoređivanje oficira po završetku školovanja/usavršavanja u značajnoj meri utiče na dalji razvoj njegove karijere" ( $F=3,583 ; p=0,029)$; 5$)$ varijabla „stepen obrazovanja“ (1/visoko; 2/master; 3/specijalizacija; 4/magistar; 5/doktor nauka) i za indikator: „Na razvoj karijere oficira utiču brojni faktori“ $(F=3,312 ; p=0,021) ; 6)$ varijabla „ocena sa školovanja“ $(1 / 6,00$ $7,00 ; 2) 7,01-8,00 ; 3) 8,01-9,00,4 / 9,01-10,00)$ i za indikator: „Uprava za kadrove SLjR MO u dovoljnoj meri obezbeđuje potrebne informacije o mogućnostima za razvoj karijere oficira" ( $F=3,159 ; p=0,026)$ i 7$)$ varijabla "najviše vojno obrazovanje“ (1/vojna gimnazija ili srednja vojna škola; 2/vojna akademija; 3/specijalizacija; 4/ magisterijum i 5/doktorat) i za indikator „Na razvoj karijere oficira utiču brojni faktori“ $(F=3,024 ; p=0,019)$. 
Razlike u proceni uticaja uspešnosti realizacije procesa planiranja, selekcije, školovanja, usavršavanja i raspoređivanja na odgovarajuće dužnosti uspešnost procesa razvoja karijere oficira

Kao što je istaknuto, uspešnost procesa razvoja karijere oficira zavisi od uspešnosti realizacije procesa planiranja, selekcije, školovanja, usavršavanja i raspoređivanja na odgovarajuće dužnosti. Procena tih faza u profesionalnom razvoju oficira zavisi od nekih personalnih, statusnih i andragoških obeležja ispitanika. Shodno tome, postupkom analize varijanse utvrđeno je da među pojedinim kategorijama ispitanika postoje razlike u proceni ovih procesa u odnosu na određena njihova personalna, statusna i andragoška obeležja.

Rezultati istraživanja su pokazali da na ove procene naročito utiče „najviše vojno obrazovanje" ispitanika (1/vojna gimnazija ili srednja vojna škola; 2/vojna akademija; 3/specijalizacija 4/ magisterijum; 5/doktorat). Značajna razlika među grupama ispitanika utvrđena je kod dva indikatora: 1) „Raspoređivanje oficira na dužnost nakon završetka usavršavanja trebalo bi da se prvenstveno obavlja na osnovu postignutog uspeha tokom usavršavanja“ ( $F=3,541 ; p=0,008)$ i 2$)$ „U cilju pravilnog razvoja karijere, oficir bi trebao tokom radnog veka da se najmanje jednom (a poželjno i više puta) premešta iz Vojske Srbije u Ministarstvo odbrane, i obrnuto" ( $F=2,682 ; p=0,033)$ (tabela 13).

Tabela 13 - Rezultati analize varijanse- varijabla „najviše vojno obrazovanje“

\begin{tabular}{|c|c|c|c|c|c|c|}
\hline & & $\begin{array}{c}\text { Sume } \\
\text { kvadriranih } \\
\text { odstupanja }\end{array}$ & $\begin{array}{c}\text { Broj } \\
\text { stepeni } \\
\text { slobode }\end{array}$ & $\begin{array}{c}\text { Ocene } \\
\text { varijansi } \\
\text { između i } \\
\text { unutar } \\
\text { grupa }\end{array}$ & $\underset{\text { statistik }}{\mathrm{F}}$ & $\begin{array}{c}\text { Nivo } \\
\text { značaj- } \\
\text { nosti }\end{array}$ \\
\hline \multirow[t]{3}{*}{$\begin{array}{l}\text { RAZVKARPLAN } \\
\text { IR }\end{array}$} & $\begin{array}{l}\text { Između } \\
\text { grupa }\end{array}$ & 1.318 & 4 & \multirow[t]{3}{*}{.330} & \multirow[t]{3}{*}{.556} & \multirow[t]{3}{*}{.695} \\
\hline & $\begin{array}{l}\text { Unutar } \\
\text { grupa }\end{array}$ & 126.929 & 214 & & & \\
\hline & Ukupno & 128.247 & 218 & & & \\
\hline \multirow[t]{3}{*}{$\begin{array}{l}\text { RAZVKARPSEL } \\
\text { EK }\end{array}$} & $\begin{array}{l}\text { Između } \\
\text { grupa }\end{array}$ & .933 & 4 & \multirow[t]{3}{*}{.233} & \multirow[t]{3}{*}{.732} & \multirow[t]{3}{*}{.571} \\
\hline & $\begin{array}{l}\text { Unutar } \\
\text { grupa }\end{array}$ & 68.190 & 214 & & & \\
\hline & Ukupno & 69.123 & 218 & & & \\
\hline \multirow[t]{3}{*}{$\begin{array}{l}\text { RASPORDUZU } \\
\text { SP }\end{array}$} & $\begin{array}{l}\text { Između } \\
\text { grupa }\end{array}$ & 5.547 & 4 & \multirow[t]{3}{*}{1.387} & \multirow[t]{3}{*}{3.541} & \multirow[t]{3}{*}{.008} \\
\hline & $\begin{array}{l}\text { Unutar } \\
\text { grupa }\end{array}$ & 83.805 & 214 & & & \\
\hline & Ukupno & 89.352 & 218 & & & \\
\hline \multirow[t]{3}{*}{$\begin{array}{l}\text { VERTHORPOM } \\
\text { ERA }\end{array}$} & $\begin{array}{l}\text { Između } \\
\text { grupa }\end{array}$ & 2.480 & 4 & \multirow[t]{3}{*}{.620} & \multirow[t]{3}{*}{1.827} & \multirow[t]{3}{*}{.125} \\
\hline & $\begin{array}{l}\text { Unutar } \\
\text { grupa }\end{array}$ & 72.643 & 214 & & & \\
\hline & Ukupno & 75.123 & 218 & & & \\
\hline
\end{tabular}




\begin{tabular}{|c|c|c|c|c|c|c|c|}
\hline $\begin{array}{l}\text { DUZNOSTIMO } \\
\text { VS }\end{array}$ & $\begin{array}{l}\text { Između } \\
\text { grupa } \\
\text { Unutar } \\
\text { grupa } \\
\text { Ukupno }\end{array}$ & $\begin{array}{r}6.196 \\
123.585 \\
129.781\end{array}$ & $\begin{array}{r}4 \\
214 \\
218 \\
\end{array}$ & & $\begin{array}{r}1.549 \\
.577\end{array}$ & 2.682 & .033 \\
\hline $\begin{array}{|ll|}\text { DUZNOSTINAST } & \text { Između } \\
\text { AV } & \text { grupa } \\
& \text { Unutar grupa } \\
& \text { Ukupno }\end{array}$ & $\begin{array}{r}4.549 \\
136.556 \\
141.105\end{array}$ & $\begin{array}{r}4 \\
214 \\
218\end{array}$ & & $\begin{array}{r}1.137 \\
.638 \\
\end{array}$ & & .782 & .134 \\
\hline
\end{tabular}

RAZVKARPLANIR („Uspešnost razvoja karijere oficira umnogome zavisi od kvalitetnog planiranja razvoja starešinskog kadra“); RASPORDUZUSP („Raspoređivanje oficira na dužnost nakon završetka usavršavanja trebalo bi da se prvenstveno obavlja na osnovu postignutog uspeha tokom usavršavanja“); RAZVKARPSELEK („Pravilna selekcija oficira za upućivanje na školovanja/usavršavanja predstavlja osnovni preduslov za uspešnost u razvoju njihove karijere“); RASPORDUZUSP („Raspoređivanje oficira na dužnost nakon završetka školovanja/usavršavanja trebalo bi da se prvenstveno obavlja na osnovu postignutog uspeha tokom školovanja/usavršavanja“); VERTHORPOMERA („Pravilan razvoj karijere podrazumeva ne samo pomeranje oficira (u hijerarhiji VS/MO) po vertikali, već i po horizontali, čime se stiču dodatne stručne kompetencije“); DUZNOSTIMOVS („U cilju pravilnog razvoja karijere, oficir bi trebao tokom radnog veka da se najmanjue jednom (a poželjno i više puta) premešta iz Vojske Srbije u Ministarstvo odbrane, i obrnuto"); DUZNOSTINASTAV (',U toku profesionalne karijere, oficiri na najvišim dužnostima u Vojsci Srbije trebalo bi da provedu izvesno vreme na odgovarajućim nivoima visokoškolskog obrazovanja u ulozi nastavnika").

Razlika u proceni uspešnosti razvoja karijere oficira utvrđena je među grupama ispitanika po osnovi određenih personalnih, statusnih i andragoških obeležja ispitanika i jednog indikatora, i to: 1) varijabla „penzijski staž“ (1/do 10 godina; 2/11-20 godina; 3/21-30 godina; 4/preko 30 godina) i za indikator: „Raspoređivanje oficira na dužnost nakon završetka usavršavanja trebalo bi da se prvenstveno obavlja na osnovu „postignutog uspeha tokom usavršavanja" ( $\mathrm{F}=3,249 ; \mathrm{p}=0,023) ; 2)$ "pripadnost rodu-službi“ (1/pešadija; 2/artiljerija; 3/OMJ; 4/inžinjerija; 5/rečne jedinice; 6/ARJ PVD; 7/VOJ; 8/tehnička; 9/saobraćajna; 10/intendantska; 11)telekomunikacije; 12/informatika; 13/EI i PED; 14/avijacija; 15/finansijska služba; 16/personalna služba; 17/vojna policija; 18/sanitetska služba; 19/služba bezbednosti) i za indikator: „Uspešnost razvoja karijere oficira umnogome zavisi od kvalitetnog planiranja razvoja starešinskog kadra“ $(F=1,727 ; p=0,037) ; 3)$ varijabla "najviše vojno usavršavanje“ (1/komandno-štabno usavršavanje; 2/generalštabno usavršavanje, 3/osnovni komandno-štabni kurs i 4/ostali oblici usavršavanja) i indikator „Pravilan razvoj karijere podrazumeva ne samo pomeranje oficira (u hijerarhiji VS/MO) po vertikali, već i po horizontali, čime se stiču dodatne stručne kompetencije“ $F=5,036 ; p=0,002) ; 4$ ) varijabla „poznavanje stranog jezika" utiče na razvoj karijere oficira (1/jesu, u velikoj meri; 2/jeste, delimično; 3/nije; 4/ne znam) i indikator: „U toku profesionalne karijere, oficiri na najvišim dužnostima u 
Vojsci Srbije trebalo bi da provedu izvesno vreme na odgovarajućim nivoima visokoškolskog obrazovanja u ulozi nastavnika“ $(F=2,896 ; p=0,036)$ i 5) varijabla „završeni kursevi“ utiču na razvoj karijere oficira (1/jeste, u velikoj meri; 2/jeste; delimično; 3/nisu; 4/ne znam) i za indikator: „U toku profesionalne karijere, oficiri na najvišim dužnostima u Vojsci Srbije trebalo bi da provedu izvesno vreme na odgovarajućim nivoima visokoškolskog obrazovanja u ulozi nastavnika" ( $F=2,852 ; p=0,038)$.

\section{Razlike u proceni efekata pravilnog razvoja karijere oficira}

Rezultati istraživanja su pokazali da na procene efekata pravilnog razvoja karijere oficira naročito utiče „stepen obrazovanja oficira" (1/visoko; 2/master; 3/specijalizacija; 4/magistar; 5/doktor nauka). Značajna razlika među grupama ispitanika utvrđena je kod tri indikatora: 1) „Pravilnim razvojem karijere oficira obezbeđuje se da u jedinicama/ustanovama Vojske Srbije komanduju/rukovode najsposobniji i najkompetentniji oficiri“ ( $F=3,769 ; p=0,011) ; 2)$ „Efekti pravilnog razvoja karijere oficira direktno utiču na motivisanost starešinskog kadra za postizanje odličnih rezultata na formacijskoj dužnosti“; 3) „Efekti pravilnog razvoja karijere oficira direktno utiču na razvoj i održavanje operativnih sposobnosti njihovih jedinica, kao i Vojske Srbije u celini“ ( $F=4,977$; $p=0,002)$ (tabela 14).

Tabela 14 - Rezultati analiza varijanse - varijabla „stepen obrazovanja“

\begin{tabular}{|c|c|c|c|c|c|c|}
\hline & & $\begin{array}{c}\text { Sume } \\
\text { kvadriranih } \\
\text { odstupanja }\end{array}$ & $\begin{array}{c}\text { Broj } \\
\text { stepeni } \\
\text { slobode }\end{array}$ & $\begin{array}{c}\text { Ocene varijansi } \\
\text { između i unutar } \\
\text { grupa }\end{array}$ & $\begin{array}{c}\mathrm{F} \\
\text { statistik }\end{array}$ & $\begin{array}{c}\text { Nivo } \\
\text { značajnosti }\end{array}$ \\
\hline \multirow[t]{3}{*}{ OPTKORLjMRES } & Između grupa & 6.330 & 3 & 2.110 & 4.261 & .006 \\
\hline & Unutar grupa & 106.447 & 215 & .495 & & \\
\hline & Ukupno & 112.776 & 218 & & & \\
\hline \multirow[t]{3}{*}{ KOMANDNAJSPO } & Između grupa & 3.306 & 3 & 1.102 & 3.769 & .011 \\
\hline & Unutar grupa & 62.867 & 215 & .292 & & \\
\hline & Ukupno & 66.174 & 218 & & & \\
\hline \multirow[t]{3}{*}{ MOTIVACODLREZ } & Između grupa & 3.640 & 3 & 1.213 & 7.735 & .000 \\
\hline & Unutar grupa & 33.729 & 215 & .157 & & \\
\hline & Ukupno & 37.370 & 218 & & & \\
\hline \multirow[t]{3}{*}{ MOTIVACPROFRAZ } & Između grupa & 3.362 & 3 & 1.121 & 2.614 & .052 \\
\hline & Unutar grupa & 92.199 & 215 & .429 & & \\
\hline & Ukupno & 95.562 & 218 & & & \\
\hline \multirow[t]{3}{*}{ OPERATIVNESPO } & Između grupa & 3.728 & 3 & 1.243 & 4.977 & .002 \\
\hline & Unutar grupa & 53.678 & 215 & .250 & & \\
\hline & Ukupno & 57.406 & 218 & & & \\
\hline
\end{tabular}


OPTKORLjMRES („Efekti pravilnog razvoja karijere oficira značajno doprinose optimalnoj iskorišćenosti ljudskih i materijalnih resursa njihovih jedinica“); KOMANDNAJSPO („Pravilnim razvojem karijere oficira, obezbeđuje se da u jedinicama/ustanovama Vojske Srbije komanduju/rukovode najsposobniji i najkompetentniji oficiri“); MOTIVACODLREZ („Efekti pravilnog razvoja karijere oficira direktno utiču na motivisanost starešinskog kadra za postizanje odličnih rezultata na formacijskoj dužnosti“); MOTIVACPROFRAZ („Pravilan razvoj karijere oficira umnogome utiče na motivisanost starešinskog kadra za profesionalnim razvojem u struci (obrazovanje tokom života“); OPERATIVNESPO („Efekti pravilnog razvoja karijere oficira direktno utiču na razvoj i održavanje operativnih sposobnosti njihovih jedinica, kao i Vojske Srbije u celini“).

Razlika u proceni efekata pravilnog razvoja karijere oficira utvrđena je među grupama ispitanika po osnovi određenih personalnih, statusnih i andragoških obeležja ispitanika i jedne nezavisne varijable, i to: 1) varijabla „starost“ (1/do 35 godina; 2/35-40 godina; 3/40-45 godina; 4/preko 45 godina) i za indikator „Pravilan razvoj karijere oficira umnogome utiče na motivisanost starešinskog kadra za profesionalnim razvojem u struci (obrazovanje tokom života)" ( $F=4,300 ; p=0,006)$; 2) varijabla „penzijski staž“" (1/do 10 godina; 2/11-20 godina; 3/21-30 godina; 4/preko 30 godina) i za indikator „Pravilan razvoj karijere oficira umnogome utiče na motivisanost starešinskog kadra za profesionalnim razvojem u struci (obrazovanje tokom života)" ( $F=2,851$; $p=0,038)$ i 3) varijabla "čin“ (1/poručnik; 2/kapetan; 3/major; 4/potpukovnik; 5/pukovnik) i za indikator „Pravilan razvoj karijere oficira umnogome utiče na motivisanost starešinskog kadra za profesionalnim razvojem u struci (obrazovanje tokom života)" (F=5,606; $p=0,000)$. Prezentovani rezultati istraživanja upućuju na zaključak da su efekti pravilnog razvoja karijere oficira višestruki.

I na kraju, svi prezentovani rezultati, kao i zaključci po pojedinim pitanjima ukazuju na to da je „Razvoj karijere oficira determinisan brojnim činiocima“.

\section{Zaključak}

Uspešnost razvoja karijere oficira predstavlja jednu od najznačajnijih tema u oblasti ljudskog ponašanja u vojnoj organizaciji, jer od stepena uspešnosti tog procesa u velikoj meri zavisi stepen zadovoljstva oficira poslom, a samim tim nivo osposobljenosti vojnoorganizacionih jedinica. Problematika uspešnosti razvoja karijere oficira je veoma složena i predstavlja osnovu za motivisanje oficira i razvoj njihovog zadovoljstva poslom, kao i za podizanje nivoa operativnih sposobnosti vojnoorganizacionih jedinica kojima rukovode.

Nezavisne varijable u ovom radu su činili pojedini uticajni činioci razvoja karijere oficira, a zavisnu varijablu je činila procena uticaja pojedinih činilaca na razvoj karijere oficira. Svaka nezavisna varijabla ima određen broj indikatora pomoću kojih je razmatran uticaj pojedinih činilaca na razvoj karijere oficira, kao i razlike među pojedinim kategorijama oficirima po pitanju procene uticaja pojedinih činilaca na razvoj karijere oficira u odnosu na njihova personalna, statusna i andragoška obeležja ispitanika.

Prvi istraživački zadatak se odnosio na uticaj „Normativno-pravnih pretpostavki na uspešan razvoj karijere oficira“. Ova relacija je ispitivana pomoću pet indikatora. Kada je reč o „Uredbi o stanjima u službi i unapređivanju oficira, podoficira i profesionalnih vojnika i njenom uticaju na razvoj karijere oficira", svega 22 odsto ispitanika se izjašnjava u prilog ovoj tvrdnji. Nešto bolji rezultati su postignuti u oceni doprinosa „Ponovnog uvođenja ispita za čin majora“ 
u model profesionalnog usavršavanja oficira (38,4\%). Nešto veći procenat ispitanika se izjasnio u prilog uticaja "Zakona o Vojsci Srbije na pravilan i ravnomeran razvoj karijere oficira“ $(38,8 \%)$. Međutim, nešto manji procenat ispitanika ocenjuje da 'Godišnji plan školovanja i obuke u Ministarstvu odbrane predstavlja najvažniji dokument u sklopu individualnog planiranja razvoja karijere oficira (32,9\%). Na kraju analize prvog istraživačkog zadatka zaključeno je da „Normativno-pravne pretpostavke delimično obezbeđuju uspešan razvoj karijere oficira“

Drugi istraživački zadatak obuhvatao je ispitivanje uticaja više subjekata (od oficira kao pojedinaca, preko pretpostavljenih starešina i komandi, do subjekata upravljanja ljudskih resursa na svim nivoima razvoja) na razvoj karijere oficira. $U$ vezi s tim, ispitanicima je postavljeno pitanje koji je njihov željeni tip karijere, a zatim koji im je tip karijere određen. Na osnovu rezultata istraživanja, najveći procenat željenih tipova karijera se odnosi na komandno-operativnu $(60,7 \%)$, a da je najveći procenat ispitanika raspoređen na komandno-operativne dužnosti $(72,1)$. Rezultati istraživanja su pokazali da na razvoj karijere oficira najviše utiču pretpostavljene starešine (32,9\%). U odgovoru na pitanje „Da li može pripadnost određenom rodu-službi u značajnoj meri uticati na razvoj karijere oficira", rezultati istraživanja su pokazali da čak $75,3 \%$ ispitanika smatra da ovaj indikator predstavlja determinišući faktor za profesionalni razvoj oficira. Raspoređivanje oficira na dužnosti nakon završetka školovanja ima značajan uticaj na razvoj karijere oficira, što je potvrdilo 88,1 odsto ispitanika. Istraživanjem je potražen odgovor na pitanje „Da li socijalna mreža (grupisanje) u smislu geografskog porekla, rođačkih linija i slično u značajnom procentu utiče na razvoj karijere oficira. Prema rezultatima istraživanja, preko 40 odsto ispitanika smatra da ovaj indikator značajno utiče na profesionalni razvoj karijere. Preko 60 odsto ispitanika se izjasnilo da Uprava za kadrove SLjR MO u nedovoljnoj meri obezbeđuje potrebne informacije o mogućnostima za razvoj karijere oficira. Nakon sprovedene analize statističkih pokazatelja zaključeno je da u procesu razvoja karijere oficira aktivno učestvuje više subjekata od oficira kao pojedinaca, preko pretpostavljenih starešina i komandi, do subjekata upravljanja ljudskih resursa na svim nivoima.

Treći istraživački zadatak je obuhvatao ispitivanje pretpostavke da li uspešnost procesa razvoja karijere oficira zavisi od uspešnosti realizacije procesa planiranja, selekcije, školovanja, usavršavanja i raspoređivanja na odgovarajuće dužnosti. Rezultati istraživanja su pokazali da 70 odsto ispitanika smatra da uspešnost razvoja karijere oficira umnogome zavisi od kvalitetnog planiranja razvoja starešinskog kadra. Prema rezultatima istraživanja, preko 80 odsto ispitanika smatra da pravilna selekcija oficira za upućivanje na školovanje/usavršavanje predstavlja osnovni preduslov za uspešnost u razvoju karijere oficira. Oko 50 odsto ispitanika se slaže sa tvrdnjom da bi raspoređivanje oficira na dužnost nakon usavršavanja trebalo da se prvenstveno obavlja na osnovu postignutog uspeha tokom usavršavanja. U vojnoj profesiji, razvoj karijere oficira podrazumeva horizontalno i vertikalno pomeranje u toku profesije. Kada je reč o horizontalnom pomeranju oficira, ispitanici su se u većini složili s tvrdnjom da ono obezbeđuje dodatne stručne kompetencije (84,9\%). Više od 50 odsto ispitanika se izjasnilo da bi oficiri trebali da se tokom radnog veka najmanje jednom premeštaju iz Vojske Srbije u Ministarstvo odbrane, i obrnuto. Takođe, oko 50 odsto ispitanika smatra da bi oficiri tokom profesionalne karijere trebali da provedu izvesno vreme u vojnoškolskim ustanovama na nastavničkim dužnostima. Rezultati statističke analize u okviru trećeg istraživačkog zadatka su potvrdili da uspešnost procesa razvoja karijere oficira zavisi od uspešnosti realizacije procesa planiranja, selekcije, školovanja, usavršavanja i raspoređivanja na odgovarajuće dužnosti. 
Četvrti istraživački zadatak je obuhvatao ispitivanje pretpostavke da su efekti pravilno sprovedenog procesa razvoja karijere oficira višestruki, i da se ogledaju u efektivnoj iskorišćenosti ljudskih potencijala jedinice, što u značajnoj meri utiče na razvoj o održavanje operativnih sposobnosti Vojske Srbije u celini. Prema rezultati istraživanja, najveći procenat ispitanika smatra da efekti pravilnog razvoja karijere oficira doprinose optimalnoj iskorišćenosti ljudskih i materijalnih potencijala $(77,6 \%)$. U visokom procentu se ispitanici izjašnjavaju da efekti pravilnog razvoja oficira doprinose da jedinicama/ustanovama Vojske Srbije komanduju/rukovode najsposobniji i najkompententniji oficiri $(81,7 \%)$. Još veći procenat ispitanika se izjasnio u prilog tvrdnji da pravilan razvoj karijere oficira neposredno utiče na motivisanost starešinskog kadra za postizanje odličnih rezultata na dužnosti $(92,7 \%)$. Preko 80 odsto ispitanika se složilo s tvrdnjom da pravilan razvoj karijere oficira utiče na motivisanost oficirskog kadra za profesionalnim razvojem u struci. Takođe, visok procenat ispitanika se izjasnio u prilog tvrdnji da efekti pravilnog razvoja karijere oficira utiču na razvoj i održavanje operativnih sposobnosti jedinica-ustanova kojima rukovode $(90,4 \%)$. Na osnovu analize statističkih pokazatelja u okviru četvrtog istraživačkog zadatka zaključeno je da su efekti pravilno sprovedenog procesa razvoja karijere oficira višestruki, i da se ogledaju u efektivnoj iskorišćenosti ljudskih potencijala jedinice, što u značajnoj meri utiče na razvoj o održavanje operativnih sposobnosti Vojske Srbije u celini.

Peti istraživački zadatak se odnosio na korelaciju između personalnih, statusnih i andragoških obeležja ispitanika i njihove procene uticaja različitih činilaca na razvoj karijere oficira. Ovo ispitivanje je obavljeno pomoću analize varijanse.

Procena uticaja normativno-pravnih pretpostavki najviše je određeno „starošću“, „činom“ i "najvišim vojnim usavršavanjem“ ispitanika. Kad je u pitanju varijabla "starost“ utvrđena je značajna razlika među grupama ispitanika po pitanju tri indikatora: 1) ponovno uvođenje polaganja ispita za čin majora bi unapredilo proces razvoja karijere oficira; 2) normativno-pravne pretpostavke čine proces razvoja karijere oficira u dovoljnoj meri predvidivim i 3) odredbe Zakona o Vojsci Srbije omogućavaju pravilan i ravnomeran razvoj karijere oficira. Prilikom razmatranja statusnog obeležja „čina“ utvrđene su takođe značajne razlike među grupama ispitanika za tri indikatora: 1) ponovno uvođenje polaganja ispita za čin majora bi unapredilo proces razvoja karijere oficira; 2) normativno-pravne pretpostavke čine proces razvoja oficira predvidivim u dovoljnoj meri i 3) odredbe Zakona o Vojsci Srbije omogućuju pravilan i ravnomeran razvoj karijere oficira. U istraživanju je utvrđena značajna razlika među grupama ispitanika po pitanju varijable „najviše vojno usavršavanje" za četiri indikatora: 1) uredba o stanjima u službi i unapređivanju oficira, podoficira i profesionalnih vojnika u potpunosti omogućava uslove za adekvatan razvoj karijere oficira; 2) ponovno uvođenje polaganja ispita za čin majora bi unapredilo proces razvoja karijere oficira; 3 ) normativno-pravne pretpostavke čine proces razvoja oficira u dovoljnoj meri predvidivim i 4) odredbe Zakona o Vojsci Srbije omogućuju pravilan i ravnomeran razvoj karijere oficira. Značajna razlika među grupama ispitanika je utvrđena i kod varijable „penzijski staž“ za dva indikatora: 1) ponovno uvođenje polaganja ispita za čin majora bi unapredilo proces razvoja karijere oficira i 2) normativno-pravne pretpostavke čine proces razvoja oficira u dovoljnoj meri predvidivim.

Rezultati istraživanja su pokazali da su na procenu uticaja različitih subjekata upravljanja ljudskim resursima na razvoj karijere oficira najviše uticali „čin " i „najviše vojno usavršavanje“. Prilikom razmatranja varijable „čin“ utvrđena je razlika među grupama ispitanika po pitanju dva indikatora: 1) na razvoj karijere oficira utiču brojni subjekti i 2) socijalna mreža (grupisanje) u smislu geografskog porekla, rođačkih linija i slično u značajnom procentu utiče na raz- 
voj karijere oficira. I prilikom ispitivanja uticaja obeležja „najviše vojno usavršavanje“ utvrđene su značajne razlike među grupama ispitanika po pitanju dva indikatora: 1) na razvoj karijere oficira utiču brojni subjekti i 2) socijalna mreža (grupisanje) u smislu geografskog porekla, rođačkih linija i slično u značajnom procentu utiče na razvoj karijere oficira.

Kad je u pitanju procena uspešnosti realizacije procesa planiranja, selekcije, školovanja, usavršavanja i raspoređivanja na odgovarajuće dužnosti tih faza u profesionalnom razvoju oficira, rezultati istraživanja su pokazali da na tu procenu naročito utiče „najviše vojno obrazovanje“ ispitanika. Značajna razlika među grupama ispitanika utvrđena je kod dva indikatora: 1) raspoređivanje oficira na dužnost nakon završetka usavršavanja trebalo bi da se prvenstveno obavlja na osnovu postignutog uspeha tokom usavršavanja i 2) u cilju pravilnog razvoja karijere, oficir bi trebao tokom radnog veka da se najmanje jednom (a poželjno i više puta) premešta iz Vojske Srbije u Ministarstvo odbrane, i obrnuto.

Razlika u proceni uspešnosti razvoja karijere oficira utvrđena je među grupama ispitanika po osnovi sledećih personalnih, statusnih i andragoških obeležja ispitanika i jednog indikatora, i to: 1) varijabla „penzijski staž“ i za indikator: „raspoređivanje oficira na dužnost nakon završetka usavršavanja trebalo bi da se prvenstveno obavlja na osnovu postignutog uspeha tokom usavršavanja“; 2) varijabla „pripadnost rodu-službi“ i za indikator: „uspešnost razvoja karijere oficira umnogome zavisi od kvalitetnog planiranja razvoja starešinskog kadra“; 3) varijabla "najviše vojno usavršavanje“ i indikator "pravilan razvoj karijere podrazumeva ne samo pomeranje oficira (u hijerarhiji VS/MO) po vertikali, već i po horizontali, čime se stiču dodatne stručne kompetencije“; 4)varijabla „poznavanje stranog jezika“ utiče na razvoj karijere oficira i indikator: „u toku profesionalne karijere, oficiri na najvišim dužnostima u Vojsci Srbije trebalo bi da provedu izvesno vreme na odgovarajućim nivoima visokoškolskog obrazovanja u ulozi nastavnika“ i 5)varijabla „završeni kursevi“ utiču na razvoj karijere oficira i za indikator: „u toku profesionalne karijere, oficiri na najvišim dužnostima u Vojsci Srbije trebalo bi da provedu izvesno vreme na odgovarajućim nivoima visokoškolskog obrazovanja u ulozi nastavnika“.

Rezultati istraživanja su pokazali da na procenu efekata pravilnog razvoja karijere oficira naročito utiče „stepen obrazovanja oficira“. Značajna razlika među grupama ispitanika utvrđena je kod tri indikatora: 1) pravilnikom razvoja karijere oficira obezbeđuje se da u jedinicama/ustanovama Vojske Srbije komanduju/rukovode najsposobniji i najkompetentniji oficiri; 2) efekti pravilnog razvoja karijere oficira direktno utiču na motivisanost starešinskog kadra za postizanje odličnih rezultata na formacijskoj dužnosti; 3) efekti pravilnog razvoja karijere oficira direktno utiču na razvoj i održavanje operativnih sposobnosti njihovih jedinica, kao i Vojske Srbije u celini.

I na kraju, svi prezentovani rezultati, kao i zaključci po pitanju svih pet istraživačkih zadataka ukazuju na to da je razvoj karijere oficira u značajnoj meri determinisan brojnim činiocima. To upućuje na zaključak da bi u nastavku reforme sistema odbrane trebalo intenzivirati promene i poboljšanja u upravljanju ljudskim resursima, što bi moglo dovesti do uspešnijeg razvoja karijere njegovih pripadnika. Shodno tome, neophodno je sagledati sve raspoložive mogućnosti za adekvatno i planiranje ljudskih resursa i razvoj karijere svih kategorije lica u sistemu odbrane.

\section{Literatura}

[1] Adižes I. (1979), Životni ciklus preduzeća, Prometej, Novi Sad.

[2] Antić B. (2001), Razvoj generalštabne službe i osobine generalštabnog oficira, Vojno delo 2 / 2011.

[3] Babić M. (1999), Menadžment: struktura i funkcija, KIZ Centar, Beograd. 
[4] Bahtijarević- Šiber F. (1999), Menadžment ljudskih potencijala, Golden marketing, Zagreb,

[5] Bogićević B. (2004), Menadžment ljudskih resursa, Ekonomski fakultet, Beograd.

[6] Veština upravljanja (1994), GIP „Slobodan Jović“, Beograd.

[7] Vuksan B. (1999), Teorija organizacije, ICIM, Kruševac.

[7] Gajić, Ž. (2008), Menadžment ljudskih resursa u sektoru bezbednosti (doktorska disertacija), Fakultet organizacionih nauka Beograd, Beograd.

[7] Grinberg Dž., Baron R. A. (1998), Ponašanje u organizacijama - razumevanje i upravljanje ljudskom stranom rada, Želdin, Beograd.

[18] Damnjanović P. (2001), Osnovna polazišta u školovanju oficirskog kadra, Novi glasnik br. 6/2001.

[11] Desler G. (2007), Osnovi menadžmenta ljudskih resursa, Data status, Beograd.

[12] Doknić, N. (2002), Menadžment kadrova, Evropski univerzitet za internacionalni menadžment i biznis, Beograd.

[13] Drucker, P. (1996), Inovacije i preduzetništvo, Grmeč-Privredni pregled, Beograd,

[14] Đorđević S. (2007), Upravljanje ljudskim resursima u sistemu odbrane RS, ŠNO-GŠU, Beograd.

[15] Jantan, H., Hamdan, A., Othman, Z. (2010), Intelligent Techniques for Decision Support System in Human Resource Management, Decision Support Systems Advances.

[16] Jovanović B (1984), Uvod u teoriju rukovođenja, VIZ, Beograd.

[17] Jurubescu, T. (2008), Human resource management - theoretical approach, Romanian Military Thinking, 4/2008.

[18] Kavran D. (1991), Organizacija, kadrovi i rukovođenje, Naučna knjiga, Beograd.

[19] Kostić P. (1989), Selekcija ljudstva i produkcija prilagođenosti zahtevima vojne organizacije (doktorska disertacija), Filozofski fakultet, Sarajevo.

[20] Kostić, P. (1989), Poželjne osobine ličnosti oficira nekih savremenih armija, Zbornik radova Vojne akademije Kopnene vojske, Beograd.

[21] Kriterijumi za izradu liste kandidata za potrebe selekcije u okviru karijernog vođenja i savetovanja u Ministarstvu odbrane i Vojsci Srbije („SVL br. 10/2012“).

[22] Kriterijumi za formiranje lista kandidata za postavljenje na formacijsko mesto višeg čina, za upućivanje na školovanje i usvršavanje i za unapređenje u viši čin („SVL br. 13/2012“).

[23] Kulić Ž. (2005), Upravljanje ljudskim potencijalima, Radnička štampa, Beograd.

[24] Kukoleča S. (1972), Osnovi teorije organizacionih sistema, PFV „Oesonotika“, Beograd.

[25] Lojić R., Kulić Ž. (2009), Menadžment ljudskih resursa, VIZ, Beograd.

[26] Malešević $Đ$. (2001), Rukovođenje, Fakultet organizacionih nauka, Beograd.

[27] Marković D. (2001), Polazne osnove pri izboru kandidata za postavljanje oficira na dužnost, Vojno delo br. 1/2001.

[28] Marković D. (2001), Uticaj kadrovanja na komandovanje, Vojno delo br. 3/2001.

[29] The Defense Integrated Military Human Resources System (2005), Ministry of Defence USA.

[30] Mihailović D. (1999, Metodologija naučnih istraživanja, Beograd.

[31] Orlić R. (2005), Kadrovski menadžment, Zoran Damljanović i sinovi, Beograd.

[32] Officer career development handbook (OCDH) (2005), Akademija za odbranu Velike Britanije.

[33] Petković M. (2005), Organizaciono ponašanje, Ekonomski fakultet, Beograd.

[34] Petković M. (2003), Organizacija, Ekonomski fakultet, Beograd.

[35] Petrović M. (1992), Rukovođenje, Fakultet organizacionih nauka, Beograd.

[36] Pravilnik o kriterijumima za izbor kandidata za polaznike stručnog osposobljavanja („SI. glasnik RS“, br. 72/2007, 21/2009 i 48/2010). 
[37] Pravilnik o kriterijumima za ocenjivanje civilnih lica na službi u Vojsci Srbije („Sl. glasnik RS“, br. 7/2009).

[38] Price, A. (1972), Human Resource Management in a Business Context, Thomson Business Press.

[39] Program upravljanja ljudskim resursima sistema odbrane Republike Srbije, (nacrt), 2008, Uprava za kadrove Sektora za ljudske resurse MO RS.

[40] Pržulj Ž. (2002), Menadžment ljudskih resursa, Institut za razvoj malih i srednjih preduzeća, Beograd.

[41] Rajkov M. (1996), Ljudska strana menadžmenta, Beograd.

[42] Regodić, D. (2005), Nužni preduslovi za perspektivno školovanje u vojnoj akademiji, Novi glasnik br. 2/2005.

[43] Ristić S. (2008), Rukovođenje kadrovima u sistemu odbrane Republike Srbije, ŠNO-GŠU, Beograd.

[44] Sektor za ljudske resurse MO Republike Srbije (2006), Studija informacionog sistema ljudskih resursa, Beograd.

[45] Tadić, S. (2004), Reforma sistema odbrane i višak vojnog kadra”, Novi glasnik br. 1/2004.

[46] Todorović, J., Đuričin, D., Janošević, S. (1998), Strategijski menadžment, Institut za tržišna istraživanja, Beograd.

[47] Todorović S.(2001), Profesija oficira, Vojno delo, 4-5/2001.

[48] Hall, D. T. (1996): Career Development in Organizations, Jossey-Bass, San Francisco,.

49] Cascio, W. F. (1995), Managing Human Resources Productivity, Quality of Work Life, Profits, 4th ed., McGraw Hill, New York.

[50] Ćamilović S. (2007), Osnovi menadžmenta ljudskih resursa, FON, Beograd.

[51] Ćamilović, S. (2000): Kadrovski procesi, Tekon, Beograd.

[52] Ćamilović S. (1996), Poslovi i organizacija kadrovske funkcije, Kultura, Beograd.

[53] Uprava za ljudske resurse (J-1) GŠ VS, Doktrina upravljanja ljudskim resursima Vojske Srbije, Beograd, 2012.

[54] Uredba o načelima i kriterijumima za unutrašnje uređenje i sistematizaciju radnih mesta u Ministarstvu odbrane („Sl. glasnik RS“, br. 106/2008).

[55] Uredba o ocenjivanju vojnih lica („SI. list SRJ“, br. 36/94, 42/94 - ispr. i 16/96).

[56] Uredba o prijemu u profesionalnu vojnu službu („Sl. glasnik RS“, br. 112/2008 i 34/2010).

[57] Uredba o stanjima u službi profesionalnih vojnih lica i o unapređivanju oficira i podoficira („Sl. glasnik RS“, br. 112/2008, 9/2009 i 17/2010).

[58] Zakon o odbrani („Sl. glasnik RS“, br. 116/2007, 88/2009, 88/2009 - dr. zakon i 104/2009 dr. zakon).

[59] Zakon o Vojsci Srbije („Sl. glasnik RS“, br. 116/2007 i 88/2009).

[60] Headquarters Department of the Army, DA PAM 600-3 Commissioned Officer Professional Development and Career Management, Washington, DC, 2010.

[61] Herrera, E. (2008), Facing the Challenge: Implementing the Defense Integrated Military Human Resources System, Air National Guard, U.S. Army War College,Carlisle Barracks.

[62] Čupić M. (1987), Uvod u teoriju odlučivanja“ , Naučna knjiga, Beograd, 1987.

[63] Džinović M., Dulanović Ž. (1992), Osnovi organizacije, FON, Beograd. 